\title{
LA VECINDAD CIVIL EN VIZCAYA
}

\author{
Adrián Celaya Ibarra
}

\section{PRIMERA PARTE: La vecindad civil en Vizcaya tras las últimas reformas ${ }^{1}$}

\section{El concepto de vecindad}

La vecindad civil es la circunstancia que, en España, determina la aplicación, en cuanto ley personal, del Código Civil o de una de las legislaciones forales. En el campo del Derecho Interregional, único en que tiene eficacia, no es otra cosa que lo que en el Derecho Internacional Privado se conoce como punto de conexión o de contacto, como puede serlo el domicilio o, en otro campo, la lex rei sitae o la lex loci.

No existe, por lo tanto, un paralelismo entre la vecindad y la nacionalidad, pese a las apariencias. La nacionalidad es un vínculo político, «la cualidad de pertenecer a la comunidad nacional organizada en forma de Estado», como dijo Federico de Castro (Compendio de Derecho Civil, p. 312). La condición de nacional crea una estrecha relación entre el ciudadano y el Estado, que se concreta en una amplia gama de derechos y obligaciones, la expedición de pasaporte, el derecho de residencia, la protección diplomática, el servicio militar, la participación en la vida pública, etc.

Nada semejante ocurre con la vecindad civil, que, como hemos afirmado es tan sólo un medio para conocer la ley aplicable, común o foral, en determinadas relaciones de Derecho Privado. En modo alguno se puede considerar como una pequeña nacionalidad, referida no al Estado en su conjunto sino a una parte o región del mismo, a la patria chica.

Es cierto que, a partir de la Constitución de 1978, España se ha organizado en Comunidades Autónomas, y puede ser posible hablar de una

${ }_{1}$ Esta primera parte ha sido publicada en la Revista de Derecho Privado, julio-agosto 1994. 
relación similar a la nacionalidad que relacione a las personas con la Comunidad Autónoma a que pertenecen.

Y efectivamente esta relación o vínculo (que podríamos considerar de segundo grado) existe, y está expresamente regulado en los Estatutos de Autonomía con la denominación de «condición política». A la condición política de vascos se refiere el artículo 7 del Estatuto de Autonomía del País Vasco, a la de catalanes el artículo 6 del Estatuto catalán, a la de gallegos el artículo 3 del Estatuto de Galicia, a la de andaluces el artículo 11 del de Andalucía, etc.; pero esta «condición política» no se asimila en ningún Estatuto a la vecindad civil sino que produce efectos distintos y se adquiere y se pierde de modos diferentes. La condición política, en todos los Estatutos, es equivalente a la vecindad administrativa y distinta de la vecindad civil.

La condición política se rige por normas distintas de la vecindad civil, todas ellas de Derecho Público. Puede uno ser políticamente vasco, catalán o andaluz (lo que viene determinado por la inscripción en el padrón municipal) y poseer una vecindad civil distinta que, en último caso, y excepcionalmente, se inscribirá en el Registro Civil, y que no tiene otro efecto que el de determinar la ley aplicable, sobre todo en cuanto al matrimonio y las sucesiones.

La condición política (como la nacionalidad) puede ser causa de derechos y obligaciones importantes, singularmente el derecho a participar en las elecciones locales. La vecindad civil produce un solo efecto y es en el ámbito de los conflictos de leyes, cuando actúa como ley personal.

No se comprende que sobre el concepto de vecindad civil hayan caído tantas cargas afectivas, mientras la idea (aparentemente más importante) de la condición política ha entrado en los Estatutos de Autonomía sin pena ni gloria y sin que produzca ninguna inquietud el hecho de que tal condición política (que habría que calificar de regionalidad o nacionalidad de segundo grado, conforme al artículo 2 de la Constitución) se halle sometida a una gran versatilidad pues se gana y se pierde con los cambios de domicilio.

Ciertamente que el Código Civil, tanto en su primera redacción, como en las reformas posteriores hasta la Ley 11/1990 de 15 de octubre, regula la vecindad civil con un estrecho paralelismo con la nacionalidad. Las modificaciones que se introducen en el campo de la nacionalidad vienen, no obstante, impuestas por cambios políticos y sociales que nada tienen que ver con las relaciones de vecindad.

Este paralelismo en la legislación no afecta a la verdadera naturaleza de la vecindad civil, que carece de todo contenido político y que ha sido creada con la única finalidad de resolver unos limitados conflictos de leyes. 
A lo sumo podríamos comparar la vecindad civil al domicilio (eliminando los efectos administrativos y procesales que la relación domiciliar produce), pues en muchos países (Francia, Inglaterra, Hispanoamérica, etc., las tres cuartas partes del mundo) la ley del domicilio es la que se impone como ley personal en los conflictos de leyes. España siguió en esta materia la tesis manciniana que coloca en el centro de la solución de los conflictos el principio de nacionalidad, y naturalmente el legislador no pudo resistir la tentación de crear un concepto paralelo, el de vecindad civil.

En países en los que se aplica la ley del domicilio se polemiza acerca del mismo y si ha de tomarse como referencia el domicilio de origen o el domicilio actual. El primero se acerca más a la ley nacional mientras el segundo acepta la ley domiciliar de hecho, como ocurre en el Tratado de Montevideo.

A mi juicio, la vecindad civil se aproxima más al domicilio de origen que al actual, aunque quizá se encuentre en un punto intermedio; pero si el Código Civil hubiera usado el término domicilio nada hubiera cambiado, excepto que probablemente no se hubieran suscitado algunas polémicas que provoca el término vecindad.

\section{La vecindad en el Código Civil}

El Código Civil en su primera redacción de 1888 regulaba la vecindad civil en su artículo 15 respecto del cual conviene hacer un par de observaciones importantes:

Primera. El encabezamiento de este artículo acota la materia a la que se aplica la vecindad civil como punto de conexión. No generalizaba el texto tratando de regular la sujeción de las personas a los Derechos forales o especiales, sino que se concretaba a señalar cuando es aplicable el Código Civil. Esto es bastante comprensible si se tiene en cuenta que, pese a la entrada de vocales foralistas en la Comisión General de Codificación, no se integraron en el texto del Código las instituciones forales sino que se reservó a los futuros apéndices la actualización de los diversos sistemas que se mantenían vigentes. Parecía entenderse que cada apéndice debería contener la regulación de la vecindad del territorio en que se aplicara.

Fueron precisamente los foralistas quienes exigieron que se regulara también la vecindad civil con carácter general en un sistema de reciprocidad, dado el desorden que podría producir la regulación separada. Ello dio lugar a que, sin retocar el resto de su contenido, se añadiera al artículo 15 un último párrafo en el que se decía que «las disposiciones de este artículo son de recíproca aplicación a las provincias y territorios españoles de diferente legislación civil». 
Este antecedente tiene una gran importancia porque significa la conformidad de los territorios forales en que el legislador central mantuviera una competencia general para regular la vecindad como punto de conexión que resuelve los conflictos de leyes. Cualquier otra fórmula introduciría un grave desorden en la materia conflictual, un desorden injustificable, cuando en el campo del Derecho internacional privado se están buscando leyes uniformes de conflictos.

Es cierto que el texto del Código se produce en una España unitaria, en la que no se admitía un poder legislativo para los órganos de un territorio autónomo; pero el mismo criterio se sigue en la Constitución de 1931, a pesar de que admite la competencia legislativa civil de las regiones autónomas (art. 14) y también en la de 1978, que la admite en forma bastante amplia, pero reserva al Estado la competencia exclusiva en materia de conflictos de leyes (art. 149.1.8) y, por lo tanto, también para regular la vecindad.

Segunda. Curiosamente el artículo 15 de la primera edición del Código Civil, en un texto que ha estado vigente hasta 1974, expresa claramente la función de la vecindad y las materias a las que se aplica: «Los derechos y deberes de familia, decía, los relativos al estado, condición y capacidad legal de las personas y los de sucesión testada e intestada declarados en este Código, son aplicables:»..., y a continuación se citaban las normas que regulan la vecindad civil como ley personal.

Es decir, que la vecindad no es un concepto de aplicación general sino que se ciñe a su función de punto de conexión y, además, en tres materias muy concretas que el Código especifica:

a) «Los derechos y deberes de familia». Y ciertamente esta materia es fundamental en todas las legislaciones forales. Sus especialidades se deben a que en Cataluña, Aragón, y los demás territorios forales, se regula un modo de organización familiar, que tiene que ver con la sociología e incluso con la geografía, y que presenta rasgos propios muy diferenciados.

Pero hay que subrayar que estas disposiciones se refieren a la organización y régimen patrimonial de la familia, casi nunca a las relaciones personales. Por esto, no se contradice con el artículo 15 lo que dispone el artículo 12 que ordenaba la aplicación general del título IV del libro I, relativo a las relaciones personales y forma del matrimonio, reserva justificada por la vigencia general de la tradición canónica, y que también explica que la Constitución vigente reserve la competencia exclusiva al Estado cuando se trate de las «relaciones jurídico civiles referentes a las formas del matrimonio» (art. 149). 
b) «Los (derechos y deberes) relativos al estado, condición y capacidad legal de las personas». Son escasas las normas relativas a esta materia en las leyes forales. Pueden anotarse las relativas a la investigación de la paternidad en Cataluña (arts. 4 a 6) o a los hijos en Aragón (arts. 4 a 14) y algunas otras que generalmente mantienen las líneas generales del Código Civil. Es una excepción notable la de Navarra, cuya Compilación dedica las leyes 42 a 52 a las personas jurídicas, entidades sin personalidad jurídica y capacidad de las personas individuales; pero hay que reconocer que, en su conjunto, estas leyes modifican muy poco la doctrina del Código, más bien la completan e interpretan.

c) En último lugar, según el antiguo artículo 15, la vecindad civil determina los derechos de «sucesión testada e intestada» que ciertamente constituyen una parte esencial en todas las legislaciones forales. Hay que destacar la referencia del Código a la sucesión intestada, que no evitó la posterior jurisprudencia del Tribunal Supremo que extendía las normas del Código en esta materia a todos los territorios de Fuero.

En conclusión: la vecindad civil es solamente un punto de conexión que se aplica a dos materias muy concretas, el régimen matrimonial y las sucesiones, ambas estrechamente ligadas con las diferentes concepciones de la vida y la organización familiar.

También hay otras materias reguladas en las leyes forales: disposiciones sobre la propiedad y derechos reales sobre inmuebles o algunas normas de Derecho contractual, como el derecho de saca en Aragón, Navarra y Vizcaya, o la rescisión por lesión en Cataluña y Navarra.

¿Por qué el artículo 15 no mencionaba estos derechos? Aparte de que son menos esenciales en las leyes forales, hay que entender que el Código Civil no consideraba que los conflictos en estas materias se debieran regular por la ley de la vecindad. En lo que afecta a los derechos reales sobre inmuebles era muy claro el artículo 10 ordenando aplicar «las leyes del país en que estén sitos»; y aunque en los contratos no había ninguna norma de colisión, la jurisprudencia anterior había establecido que se sometían a la autonomía de la voluntad, pudiendo las partes elegir la ley aplicable.

En definitiva, la modesta función de la vecindad civil estaba destinada a regir la capacidad de las personas (escasamente regulada en las leyes forales y, en general, regida por el Código Civil), el régimen de bienes en el matrimonio y las sucesiones. Conviene dejarlo claro para poner en evidencia una de las mayores sinrazones de la reforma de la vecindad en la Ley de 1990. 


\section{Evolución posterior}

La reforma del título preliminar del C.C. en 1974 no supuso en el tema que examinamos avance alguno.

Formalmente, hay que reconocer que el texto del artículo 14 reformado que trata conjuntamente «la sujeción al Derecho común o al especial o foral», mejora la redacción anterior que estaba dedicada a regular con cierta extensión la vecindad de las personas sometidas al Código Civil para declarar en el párrafo final que «estas disposiciones son de recíproca aplicación a las provincias y territorios españoles de diferente legislación». En el orden material se echa de menos la claridad con la que el antiguo artículo 15 determinaba las materias a las que se aplica la vecindad civil como punto de conexión, aunque está claro que no pueden ser otras que las que antes hemos enumerado.

Los derechos reales y su publicidad sobre los bienes muebles o inmuebles se rigen por «la ley del lugar en que se hallen» sin dependencia alguna de la vecindad. (art. 10.1). Y en cuanto a las obligaciones contractuales el artículo 10.5 aplica «la ley a la que las partes se hayan sometido expresamente». Solamente a falta de pacto se aplica la ley nacional común, que en Derecho interregional, y siempre en esta forma subsidiaria, es la ley de la vecindad común.

La vecindad civil, igual que en la redacción original del Código, juega su papel en materia de régimen de bienes en el matrimonio y en la sucesión mortis causa.

Por lo demás, las reglas del nuevo artículo 14 son materialmente las mismas que las del artículo 15 antiguo, con la añadidura de algunos problemas más bien formales.

La reforma producida por la Ley 11/1990 de 15 de octubre bajo el pretexto de eliminar del Código las discriminaciones por razón de sexo, aunque mantiene la regulación básica ya tradicional, introduce unas modificaciones, en especial sobre la vecindad de la mujer casada que debemos comentar por su gran repercusión en Vizcaya.

\section{La Constitución de 1978}

La Constitución española de 1978 dice en su artículo 14 que «los españoles son iguales ante la ley sin que pueda prevalecer discriminación alguna por razón de nacimiento, sexo, religión, opinión o cualquier otra condición o circunstancia personal o social».

El artículo 32 añade que «el hombre y la mujer tienen derecho a contraer matrimonio con plena igualdad jurídica». Evidentemente la igualdad jurídica no exige el mantenimiento de vecindades distintas por 
marido y mujer; y, al contrario, ésta puede ser la causa de fuertes desigualdades.

Ambos textos mantienen un criterio de igualdad entre los sexos de justicia innegable, aceptado fervorosamente por la opinión pública. Sin duda que imponen la eliminación de una serie de disposiciones que en nuestras leyes civiles ponían a la mujer casada en total subordinación al marido, como ocurría con los artículos 56 y siguientes del Código Civil.

Aunque mi opinión vaya contra corriente, no puedo ocultar que creo que la no discriminación no supone dejar de tener en cuenta las diferencias. No se discrimina a una persona por no permitirle acceder a una oposición para la que carece de título, como, a mi juicio, no se discriminaba a la mujer en la primera redacción del Código Civil cuando se le concedía la preferencia para la custodia de los hijos menores de tres años en caso de separación. Y tampoco pienso que había una discriminación, sino la aceptación de una diferencia (que puede tener múltiples excepciones) cuando el artículo 1.267 tenía en cuenta el sexo para calificar la gravedad de la intimidación, de igual modo que sigue teniéndose en cuenta la edad, y nadie dirá que se trata de una discriminación de los niños o los ancianos.

En lo que atañe a los conflictos de leyes, la Ley de 13 de julio de 1982 se inspiró en el principio de no discriminación para regular la nacionalidad de la mujer casada y estimo que esto estaba muy justificado, porque la nacionalidad no es un simple punto de conexión para hallar la ley aplicable, sino que supone la atribución de una cualidad personal con una serie de derechos y deberes fundamentales en materia de estado civil.

Parece que inmediatamente se puso la mirada en la vecindad, respecto de la cual el Código mantenía aún el criterio de que la mujer seguía la condición de su marido. Sin embargo, la solución en este terreno es mucho más delicada, y nadie puede afirmar que la mujer gana ni pierde derechos por acogerse a la vecindad de su marido. Mantener su vecindad civil puede suponerle quedar discriminada.

Según algunas opiniones, el artículo 14 del Código resultaba inconstitucional en este punto. No se tenía en cuenta que el Código buscaba la conservación de otro principio más importante, que brota del artículo 39.1 de la Constitución y es el de mantener la unidad y cohesión de la familia. «Los poderes públicos, dice el artículo citado, aseguran la protección social, económica y jurídica de la familia.»

La protección jurídica de la familia aconseja que una sola legislación se aplique a todos sus miembros, pues lo contrario sí que sería inconstitucional, ya que supondría una verdadera discriminación entre sus miembros. Y puesto a elegir una ley para la familia, es inimaginable que el legislador en 1888 hubiera pensado en concederle otra que la del marido. 
Todas las legislaciones europeas lo hacían, incluso atribuyendo a la mujer la nacionalidad del marido, y no podía pensarse de otra forma con la mentalidad de los hombres del siglo XIX y primeros años del siglo XX.

La falta de una unidad jurídica para la familia plantea problemas de los que en seguida trataremos y muy especialmente en el País Vasco. La actual consideración social de la mujer obliga a meditar algo más sobre lo que el legislador anterior hizo, y probablemente, a no decidir «a priori» la aplicación de la ley del marido, puesto que hay otras posibilidades de opción sin quebrantar la unidad familiar.

La incoherencia de la aplicación de la ley del marido se había constatado ya en Vizcaya hace tiempo, pues en un mundo jurídico que giraba alrededor de la propiedad familiar, se hacía muy arbitrario que cuando un hombre no aforado llegaba por matrimonio a un caserío impusiera su ley a la mujer e hijos, rompiendo todas las estructuras forales; y, del mismo modo, resulta incomprensible que el aforado que llegaba a los dominios del Código Civil impusiera en ellos unas normas que debían resultar casi incompatibles con las vigentes en territorio de Derecho común.

El Congreso de Jurisconsultos celebrado en Zaragoza en 1981 puso en claro la necesidad de meditar algo más acerca de este tema. La ponencia sobre vecindad civil partía de la idea de que la Constitución imponía la conservación de la vecindad por ambos cónyuges, y así lo afirmaba en la conclusión primera. Es decir, llevaba un camino que necesariamente imponía el reconocimiento de una doble vecindad entre marido y mujer. «El matrimonio, decía, no condiciona la vecindad de los cónyuges.»

Esta disparatada conclusión suscitó viva polémica en el Congreso. El Sr. López Medel se asombraba de que se adoptase una conclusión desconocedora de la realidad familiar, que no rige en otros países europeos, en los que se llega a imponer a la mujer el apellido del marido. Era preciso hallar el medio de dar unidad a la familia sin hacer prevalecer la ley del marido ni la de la mujer.

Finalmente, el Congreso, en su conclusión 1. a , aclamada en el pleno, matizó el principio de igualdad declarando que «debe desaparecer de la legislación el criterio de que la mujer casada adquiere necesariamente la vecindad del marido».

No debe imponerse la vecindad del marido «necesariamente», pero no se afirma que la mujer (o el marido) deban conservar su vecindad anterior. Al contrario, el párrafo segundo de la misma conclusión afirmaba que «sobre la base del criterio de unidad familiar, que igualmente emana de la Constitución, es aconsejable establecer criterios objetivos tendentes al logro de una unidad de vecindad civil en el seno del matrimonio».

No se llegó a determinar cuáles fueran estos criterios objetivos, pero está clara la idea de que la familia debe tener una única vecindad civil. 
Sorprende que la mayor parte de la doctrina española haya adoptado sin resistencia la tesis de que la Constitución impone la conservación de la vecindad de los cónyuges y que el matrimonio no la modifica en absoluto. Y esta opinión se encuentra incluso entre escritores foralistas que no es del caso enumerar.

Así se explica que el Tribunal Supremo haya seguido este criterio en la sentencia de 6 de octubre de 1986, aunque no lo aplique al caso concreto por tratarse de hechos anteriores a la Constitución de 1978. Pero el Tribunal Supremo se hace cargo de las dificultades que plantea la doble vecindad y, por ello, razona que «se ha propuesto como criterio alternativo para la determinación del régimen económico matrimonial cuando los contrayentes tienen diferente ley personal, la sustitución de la ley personal del marido por otro punto de conexión que pudiera ser la residencia habitual de los contrayentes en el momento de la celebración del matrimonio.... Sería éste un punto de conexión objetivo y común a ambos consortes, con plena satisfacción del nuevo principio de igualdad...».

Efectivamente es así; pero tampoco atenta al principio de igualdad, y es mucho más coherente con la protección de la familia, la asignación de una vecindad a los cónyuges que altere la anterior al matrimonio, siempre que no se haga atendiendo al sexo, sino por otros criterios objetivos.

Lo que no se ha meditado es que la doble vecindad rompe la igualdad jurídica entre los cónyuges; y esto lo prohíbe expresamente el artículo 32.1 de la Constitución, según el cual «el hombre y la mujer tienen derecho a contraer matrimonio con plena igualdad jurídica».

En la elaboración de la ley de 1990 no intervinieron vocales foralistas, al menos no de Vizcaya, uno de los territorios más afectados, y como viene siendo norma en los últimos años se nombró una Comisión por el Ejecutivo para elaborar el proyecto. A nadie se le oculta que la vecindad civil es un tema importante en los territorios forales y en el que la especialización privatista, que no es de presumir en todos los parlamentarios, es indispensable.

\section{La Ley 11/1990 de 15 de octubre}

El artículo 14.4 de esta ley declara llanamente que «el matrimonio no altera la vecindad civil». No obstante, se concede a cada cónyuge el derecho a optar por la vecindad del otro.

Decir que el matrimonio no altera la vecindad civil no significa que no se altere la vecindad administrativa o la condición política, ambas dependientes del nuevo domicilio matrimonial. Lo que preocupa al legislador es la vecindad civil que, según creo haber explicado, no es otra cosa que el régimen familiar, matrimonial o sucesorio. Se altera la vecindad 
administrativa y la condición política si el matrimonio supone el cambio de residencia; pero esto no parece importar al dogmatismo constitucionalista, preocupado solamente por crear una especie de cisma dentro del matrimonio.

Pese al texto legal, el matrimonio es un acto de tanta trascendencia que altera muchísimas cosas, altera el estado civil y los cónyuges salen de una familia para formar otra. ¿Puede seriamente afirmarse que nada se altera?

Si no se altera la vecindad, cada cónyuge conserva su ley de soltero y en los casos de vecindad distinta el matrimonio quedará sujeto a dos legislaciones que pueden ser muy divergentes. Se produce una desigualdad jurídica, nada constitucional, y esto da lugar a efectos perturbadores como los siguientes:

Primero. No puede haber una ley de la familia, sino una ley para cada cónyuge. Al legislador no le interesa proteger la familia sino que premeditadamente la divide y escinde.

Esto puede ser malo en cualquier parte, pero es gravísimo en Vizcaya, donde las dos vecindades, aforada y no aforada, conviven y se entremezclan en una provincia pequeña, y el paso de un río, o, con frecuencia, de una calle, supone un cambio en la ley aplicable.

A lo largo de la ría de Bilbao, a la que villas y anteiglesias se asoman en una y otra orilla, es tan fácil encontrar vecinos aforados como no aforados, y los matrimonios pueden ser muchas veces calificados de mixtos.

Es cierto que si lo desean pueden optar por una vecindad común, pero es poco realista pensar que los vizcaínos llenen de opciones el Registro Civil. La opción, en casi todos los supuestos, es una extraña especie creada para colmar escrúpulos del legislador pero que no llega al pueblo, porque, afortunadamente no está compuesto de juristas. La experiencia demuestra que la opción se utiliza excepcionalmente, porque nadie piensa en los efectos patrimoniales de la vecindad hasta que surge un problema, cuando hay que hacer una partición de bienes, o, en el mejor de los casos, al hacer testamento. El ejercicio de la opción suele ser consecuencia del consejo de un notario o de otro profesional, que acaso llegue tarde.

Entretanto, la doble vecindad produce consecuencias tan inconvenientes como las siguientes:

a) La sucesión de cada cónyuge se rige por una ley distinta. Supongamos el matrimonio de un aforado vizcaíno, por ejemplo, de Baracaldo, con mujer no aforada (de Bilbao o Portugalete). En la sucesión de su mujer no aforada, y no habiendo hijos, el marido sobreviviente tendría como legítima el usufructo de la mitad o los 
dos tercios de los bienes (arts. 837 y 838 del Código Civil) mientras, en el mismo caso, el derecho de usufructo de la mujer recaerá, según la Compilación de Vizcaya y Alava, sobre una décima parte. ¿No es esto una verdadera discriminación, precisamente nacida de no querer discriminar? Precisamente esta reflexión pesó en los redactores de la nueva ley foral para aproximar las dos legislaciones.

b) Un cónyuge aforado vizcaíno, que conforme al artículo 32 de la nueva ley foral puede otorgar testamento por comisario a favor del no aforado, no podrá ser favorecido de la misma manera (que comporta el usufructo universal del superviviente) si su cónyuge no es aforado. El poder testatorio se basa en la recíproca confianza y lo común es que se otorgue por ambos cónyuges en testamentos paralelos, en capitulaciones o en testamentos de hermandad, por lo que pierde buena parte de su sentido si no lo pueden otorgar ambos cónyuges. En todo caso, que solamente pueda uno de ellos favorecer al otro de esta forma, es una evidente discriminación. ¿Dónde queda la igualdad jurídica?

c) ¿Cómo podrá otorgar testamento mancomunado el cónyuge vizcaíno (art. 49 de la nueva ley) si su cónyuge lo tiene prohibido? (art. 669 del C.C.).

d) ¿Cómo podrán otorgar pactos sucesorios conforme a la ley de Vizcaya (arts. 72 a 82 de la nueva ley) si sólo uno de ellos es aforado y al otro se lo prohíbe el C.C.? Con el pretexto de evitar una imaginaria discriminación, el legislador se ha quedado solo discriminando.

Segundo. Una cuestión muy importante la plantea la determinación de la vecindad civil de los hijos. ¿Si los cónyuges tienen vecindad diferente qué vecindad se transmite a los hijos, habida cuenta del predominio del jus sanguinis en la tradición española?

El artículo 14 del C.C. en su versión reformada sigue resolviendo conforme al jus sanguinis esta cuestión cuando los dos cónyuges tienen la misma vecindad.

Si tienen vecindad diferente, el artículo 15.3 plantea una solución que, en realidad escamotea la cuestión principal, la de evitar que la vecindad de los hijos rompa también la unidad familiar. Empieza por un supuesto realmente excepcional, el de que el hijo sea reconocido en actos separados. Se ordena la asignación al hijo de la vecindad de quien primero lo reconozca.

Lo que debiera ser regla general se plantea como excepción. «En su defecto», sigue el artículo 14, el hijo «tendrá la vecindad del lugar de na- 
cimiento $\mathrm{y}$, en último término, la vecindad de derecho común». Una vecindad que puede ser distinta de la del padre y la de la madre. ¡Unidad familiar!

Cuando, en último término, se atribuye a los hijos la vecindad de derecho común, entiendo que se refiere a los nacidos fuera de España o aquellos que ignoran el lugar de nacimiento. Nuevamente se concede una «vis atractiva» al Código Civil, que no creo que pueda justificarse en la Constitución de 1978.

El artículo 14 pretende remediar algunos de estos males creando un nuevo derecho de opción. «Sin embargo, dice, los padres, o el que de ellos ejerza o le haya sido atribuida la patria potestad, podrán atribuir al hijo la vecindad civil de cualquiera de ellos en tanto no transcurran los seis meses siguientes al nacimiento o a la adopción.» Por si no fuera bastante difícil y excepcional el ejercicio del derecho de opción, la reforma del C.C. limita el plazo a los seis meses posteriores al nacimiento o la adopción. Es mejor que los padres se dejen de biberones y pañales y se dediquen a pensar en esa cosa tan importante que es la vecindad civil de su hijo. Se ha creado una nueva opción absolutamente inoperante.

Pero, por si esto no basta, la ley crea un nuevo derecho de opción, esta vez a favor del hijo: «En todo caso el hijo desde que cumpla catorce años y hasta que transcurra un año después de su emancipación podrá optar bien por la vecindad civil del lugar de su nacimiento, bien por la última vecindad de cualquiera de los padres.» Es seguro que esta opción va a colmar las ilusiones de los adolescentes españoles.

El Código Civil en su versión original concedía también a los hijos un derecho de opción en el primer año siguiente a la mayoría de edad (que entonces era más tardía); pero durante más de diez años como Encargado del Registro Civil único de Bilbao, en una época de gran inmigración, no he conocido una sola opción de este tipo.

Me parece que lo más sencillo hubiera sido atribuir al hijo la vecindad correspondiente a la ley que rige el régimen matrimonial de bienes, ya que al legislador le resulta tan abominable la unidad de vecindad entre cónyuges.

Tercera. Supuesta la doble vecindad de los cónyuges se hace muy difícil la determinación de la ley aplicable al régimen de bienes en el matrimonio. Tanto es así que el legislador ha tardado once años en dar solución a este problema y lo ha hecho creando algunos nuevos. Entretanto, los matrimonios celebrados entre 1978 y 1990 quedan en una situación de indefinición respecto de su régimen conyugal.

Lo único evidente es que no pueden aplicarse simultáneamente dos legislaciones diferentes y se hace preciso hallar una ley única que sea consecuente con la concepción predominante sobre la discriminación por razón de sexo. 
La conclusión tercera del Congreso de Zaragoza de 1981 decía que «en defecto de pacto» y en situación de doble vecindad, el régimen económico será determinado acudiendo a criterios objetivos, sin que se avanzara en la determinación de dichos criterios. Lo que se debería considerar es que el régimen de bienes en el matrimonio está estrechamente ligado con el sistema sucesorio y la mejor solución legislativa es la que regula el régimen económico por la ley de la vecindad común de los cónyuges, que es también la de su sucesión.

Hasta la Constitución se venía aplicando el artículo 9.3 del C.C. que, tras la reforma de 1973 aplicaba a las relaciones patrimoniales entre cónyuges, igual que a las personales, y a falta de capitulaciones matrimoniales, la última ley nacional común (aquí habría que decir ley especial o foral) y en su defecto, la ley del marido al tiempo de la celebración.

Estas normas debían ser inconstitucionales según la más corriente interpretación de la Constitución, por infringir el artículo 14, por lo que también debían ser inaplicables en Derecho interregional, según criterio que siguió el Tribunal Supremo en la sentencia que hemos citado.

En la reforma de 15 de octubre de 1990 se sustituye el artículo 9.2 por el siguiente texto (también aplicable a conflictos interregionales):

«Los efectos del matrimonio se regirán por la ley personal común de los cónyuges al tiempo de contraerlo; en defecto de esta ley, por la ley personal o de la residencia habitual de cualquiera de ellos, elegida por ambos en documento auténtico otorgado antes de la celebración del matrimonio; a falta de esta elección, por la ley de la residencia habitual común inmediatamente posterior a la celebración y, a falta de dicha residencia, por la ley del lugar de celebración del matrimonio.»

Hay en este texto un avance importante sobre la redacción anterior, que, no sabemos porqué, aplicaba la última ley nacional común, dejando indefinido el régimen matrimonial hasta que se diera esa última ley común.

Sin embargo, se observa que el artículo 9.2 omite reseñar la primera de las normas que puede resolver este conflicto, el acuerdo entre las partes, el pacto entre cónyuges, hoy admitido antes y después del matrimonio en todas las legislaciones españolas. El artículo 1.315 del Código Civil dice categóricamente que «el régimen económico del matrimonio será el que los cónyuges estipulen en capitulaciones matrimoniales».

En los estudios sobre la reforma foral que se hicieron en la Real Sociedad Bascongada de los Amigos del País se estimó siempre que debía afrontarse la solución de este problema, habida cuenta de la indefinición en que se encontraba. Aunque, por tratarse de conflictos de leyes, la solución correspondía al Estado según el artículo 149 de la 
Constitución, pensábamos que se trataba de una laguna legal en tanto no se dictase la procedente ley. Por otra parte, teníamos el antecedente de que la Compilación en su artículo 42 abordó la cuestión estableciendo que «a falta de contrato sobre los bienes, cuando el marido fuere vizcaíno infanzón en el momento de celebrarse el matrimonio, se entenderá contraído éste bajo el régimen de la comunicación foral de bienes».

La Compilación se limitaba a indicar cuándo un matrimonio se regía por la ley foral vizcaína, sin generalizar la fórmula, lo que le correspondía hacer al Estado.

Sobre esta base, el texto proyectado por la Comisión, y que pasó a integrarse en la ley vasca de 1992 es el siguiente: «Artículo 94. A falta de pacto, se entenderán sujetos a comunicación foral los matrimonios en que ambos contrayentes sean vizcaínos aforados o, a falta de vecindad común, si fijan la residencia habitual común inmediatamente posterior a su celebración en la Tierra Llana y, a falta de dicha residencia común, si en ella ha tenido lugar la celebración del matrimonio.»

Desde que se presentó el proyecto hasta su promulgación como ley transcurrió el tiempo suficiente para dar lugar a la publicación por el Estado de la Ley de 15 de octubre de 1990 que resolvió el conflicto de leyes con una disposición general, aplicable también en las legislaciones forales. Esto justifica que el Gobierno presentara ante el Tribunal Constitucional un recurso contra este artículo 94, entre otros, recurso que fue finalmente retirado, seguramente por el argumento que empleó el Consejo de Estado en su dictamen, al afirmar que el artículo 94 «sólo contiene una norma de solución de los conflictos que coincide exactamente con el juego de puntos de conexión establecido en el Código Civil con carácter general».

Es una suerte que se apreciara esta coincidencia, pero me quedan algunas dudas sobre la identidad de los dos preceptos porque:

1. La ley vasca destaca claramente como criterio básico el pacto («a falta de pacto» se inicia el art. 94) mientras el C.C. habla, y solamente en segundo término, de un documento auténtico que no conecta con los capítulos matrimoniales. Pese a ello, parece obligado admitir la prevalencia de lo pactado en capitulaciones dado el tono terminante con que el artículo 1.315 del Código establece la prevalencia de lo pactado entre los cónyuges.

2. ${ }^{\circ}$ El artículo 9.2 del Código, y ello resulta paradójico, ni siquiera emplea el término capitulaciones cuando hace aplicable el acuerdo a falta de vecindad común de los cónyuges, pues se refiere a «la ley elegida por ambos en documento auténtico otorgado antes 
de la celebración del matrimonio». Da la impresión de que se crea una fórmula de acuerdo distinta porque:

a) Las capitulaciones pueden otorgarse antes o después del matrimonio (art. 1.326 C.C.) Según el artículo 9.2 solamente antes del matrimonio. ¿Retrocedemos veinte años?

b) La libertad de los cónyuges es total en capitulaciones y solamente se les prohíbe lo que sea contrario a las leyes o a las buenas costumbres o limitativo de la igualdad de derechos que corresponda a cada cónyuge (arts. 1.325 y 1.328). En tanto que el artículo 9.2 solamente permite elegir entre la ley personal o la de residencia habitual de alguno de los cónyuges.

c) Las capitulaciones deben constar en escritura pública (art. 1.327) mientras que la elección a que se refiere el artículo 9.2 cabe hacerla en cualquier documento auténtico, que es un concepto distinto de la escritura notarial pues se refiere a cualquier documento que haga fe por sí mismo.

Parece difícil que el legislador haya querido regular algo tan diferente de las capitulaciones, tan bien conocidas en la doctrina y en la práctica y tan fáciles de otorgar. ¿Se ha tratado de crear una institución distinta? Si ello fuera así, no acierto a creer que exista una pareja de mortales, que pudiendo establecer por capítulos matrimoniales las estipulaciones que deseen, aunque tengan normas de vecindad comunes, se anime a componer este documento tan sui generis, acaso buscando la autenticidad en una forma rebuscada, que siempre será más complicada que la notarial. Si las capitulaciones son cada día más inusuales, ¿qué pasará con este nuevo invento?

Si efectivamente se trata de un título especial y distinto, me pregunto por su posible aplicación en Vizcaya, donde la nueva ley civil no la ha previsto.

Hechas estas observaciones podemos concluir que el régimen conyugal se regirá:

En primer lugar por el mutuo acuerdo de los cónyuges en escritura de capitulaciones matrimoniales, porque los artículos 1.325 y siguientes del Código no han sido derogados.

En segundo término por la ley de la vecindad común de los contrayentes.

En tercer lugar, por la ley del lugar de residencia común inmediatamente posterior a la celebración del matrimonio. Si se interpreta literalmente el C.C., en este tercer lugar debiera mencionarse el acuerdo a que se refiere el artículo 9.2.

En último lugar, por la ley del lugar de celebración del matrimonio. 


\section{La vecindad civil en la ley vasca de 1 de julio 1992}

\section{Cuestiones metodológicas}

A) Parece imprescindible aclarar algunos puntos de partida que se adoptaron en la elaboración de la nueva ley civil foral vasca, de los que puedo dar testimonio como miembro de la Comisión que preparó el proyecto y como director del seminario que en la Real Sociedad Bascongada de los Amigos del País estuvo trabajando en el tema desde la Semana de Derecho Foral de 1979 hasta las Jornadas «Vizcaya ante el siglo XXI» de 1986, elaborando el primer proyecto que se elevó a la Diputación Foral de Vizcaya.

Debo afirmar, antes de nada, que a nadie se le ocurrió la preparación de una ley uniforme para todo el País Vasco, como, al parecer, se pretende por algunos críticos actuales a quienes no es muy fácil entender. Solamente con un total desdén por lo que ha sido y es el Derecho vasco puede pensarse en una ley única impuesta por una improvisación académica donde no tiene arraigo ni tradición.

De la existencia de una Comunidad foral y un Parlamento que detenta la potestad legislativa no puede sacarse la conclusión de que sea aconsejable una ley civil uniforme. ¿A quién convencería cambiar un centralismo por otro?

Existen también las Diputaciones forales y, sobre todo, existen Alava, Guipúzcoa y Vizcaya, que tienen historias paralelas pero distintas. Y las diferencias son notables en materia de Derecho Civil ya que:

Vizcaya tiene normas forales propias perfectamente definidas y escritas desde el Fuero de 1452, reformadas en 1506 y 1526; y las costumbres que estos Fueros codificaron siguen vigentes hasta nuestros días y están muy arraigadas en las convicciones populares. Ni siquiera se nos ocurrió unificar las leyes aplicables dentro de Vizcaya porque hemos considerado que la ley civil es algo que atañe a materias esenciales para la persona y no puede ser alterada a la ligera.

Alava mantiene la vigencia del Fuero de Vizcaya en dos de sus municipios, y en el resto solamente hay disposiciones peculiares en el valle de Ayala, en el que, desde 1467 rige la Ley XXVIII del Fuero de 1373 que establece la más absoluta libertad de testar. En el resto de Alava nadie se ha preocupado de reivindicar normas especiales de Derecho civil.

En cuanto a Guipúzcoa, y probablemente a causa de su temprana integración en Castilla, nunca ha poseído normas civiles escritas y lo que se reivindica es la vigencia de costumbres nunca ordenadas en cuadernos o leyes y, en todo caso, vigentes contra ley, aunque tendentes a la conservación de la unidad de explotación del caserío como en Navarra o Vizcaya. La vigencia de estas costumbres se puso muy 
bien de relieve por juristas como Echegaray, Cillán Apalategui, Araluce y especialmente en la espléndida tesis doctoral de Alvaro Navajas Laporte. La nueva ley, fundándose en el artículo 10.5 del Estatuto de Autonomía prevé en su artículo 147 la recopilación de estas costumbres guipuzcoanas.

En estas circunstancias, si el Parlamento Vasco hubiera elaborado una ley común a todo el País Vasco, y especialmente si lo hubiera hecho para afirmar su primacía, habría cometido una arbitrariedad en obediencia a injustificados prejuicios políticos. Afortunadamente nadie propuso tal medida que solamente cabía desarrollar de dos modos: uno, aceptando las leyes de Ayala o Vizcaya para generalizarlas, lo que seguramente los alaveses y guipuzcoanos estimarían como una carga insoportable, y de otro modo, creando normas con una lejana conexión foral que se pudieran generalizar, concebidas en algún oculto laboratorio, con lo que se conseguirían dos efectos indeseables: eliminar de un tajo el Derecho de Vizcaya y utilizar la Constitución para hacer un ejercicio de inventiva que burlaría el sentido del artículo 149.

No puedo compartir la afirmación de que el País Vasco «podía haber ejercitado una competencia legislativa sin vinculación absoluta con el pasado» y que «cualquier actuación legislativa parece constitucional y estatutariamente fundada $»^{2}$ porque si así fuera no se entendería que la Constitución hubiera reservado la competencia legislativa exclusivamente a los territorios en los que el Derecho foral existe y en función de la facultad de desarrollar ese Derecho ya existente.

El Parlamento obró correctamente al encomendar la elaboración del proyecto a una Comisión designada por la Diputación de Vizcaya, en la que se integraban los juristas que hasta aquel momento habían mostrado interés por el Derecho Civil foral. Se trataba de una cuestión muy técnica en la que había que oír a los expertos, y ciertamente la mayor preocupación por estos estudios se ha manifestado siempre en Vizcaya. El Derecho civil vasco tiene su mayor contenido y extensión en Vizcaya y fue en esta provincia en la que se elaboraron los dos primeros proyectos elevados a la Diputación; e incluso existe en la Universidad de Deusto, desde 1982, una cátedra dedicada al cultivo del Derecho Foral y Autonómico vasco.

Plantear el tema como un enfrentamiento entre el Parlamento y las Instituciones de los Territorios Históricos es no solamente desconocer el problema sino tratar de enconar el clima político, que ya tiene suficientes campos de discordia.

2 Jacinto Gil Rodríguez y Javier Hualde Sánchez, en el prólogo a la edición de La ley de Derecho Civil Foral del País Vasco, Tecnos, Madrid, 1994. 
El Parlamento no hizo ninguna dejación de competencias al confiar la elaboración del proyecto a una comisión constituida en Vizcaya, sino que obró con un buen sentido que no es corriente en otros foros. Y no es correcto ocultar que aquella comisión trató de conseguir la colaboración de las otras dos provincias, y, por ello, se integró en ella el alavés Sr. Sans Uranga, que hizo un buen trabajo, pero no pudo conseguirse una colaboración guipuzcoana. Y si los juristas guipuzcoanos no quisieron participar, ¿cómo se puede culpar a los parlamentarios guipuzcoanos por su falta de iniciativa?

B) Lo expuesto justifica también que las cuestiones de vecindad se planteen en la nueva ley alrededor del Derecho vizcaíno en el que los conflictos han sido siempre los más importantes, y superan en gravedad a los que puedan surgir en cualquier otra comunidad autónoma, sobre todo por la extensión que tiene en Vizcaya el principio de troncalidad y por la dualidad legislativa que siempre ha existido en el Señorío.

Los conflictos son más limitados en Alava, aunque la pequeña dimensión del valle de Ayala, rodeado de tierras en que se aplica el Derecho común o el Fuero de Vizcaya, da lugar a que surjan con cierta frecuencia los problemas relativos a la ley aplicable. En cambio, en Guipúzcoa es imposible plantear por ahora este tema, en tanto no se desarrolle el artículo 147 de la ley foral.

C) Los redactores del proyecto de ley civil foral estábamos convencidos de la provisionalidad de nuestro trabajo, que debía simplemente poner al día nuestro Derecho Foral vigente, recogiendo las costumbres que la Compilación no amparó e incluso instituciones, como los pactos sucesorios y el testamento mancomunado, de las que no se ocupó, sin tratar de hallar formulaciones definitivas para las que aún creemos que no hay estudios suficientes. La puesta al día pretendía resolver las cuestiones que a los juristas vascos más preocupaban, pero no podía abordar el auténtico desarrollo del Derecho vasco que debe ser obra de nuevos trabajos por las nuevas promociones que, especialmente al calor de las Universidades, se están ocupando ya de esta tarea. No puede sorprendernos que en la comparación con las recientes reformas del Derecho catalán, el profesor De los Mozos no manifieste gran admiración por la ley vasca ${ }^{3}$.

Por otra parte, la dualidad de legislación existente en Vizcaya debía ser suavizada haciendo un esfuerzo para aproximarlas, cuestión que no puede ser resuelta con una ampliación del ámbito de aplicación del Derecho Foral, que supondría una violencia sobre la población afectada. De

3 José Luis de los Mozos, La legitima en «El Derecho Civil de Cataluña y en los Derechos Forales de Vizcaya y Alava» tras las últimas reformas, en Revista de Derecho Privado 1993, pp. 891 a 903 
aquí que, en muchas de las disposiciones de la nueva ley se podrá apreciar que el Derecho de Vizcaya se ha aproximado al Derecho común, como ocurre en el tema de la legítima del viudo o en la sucesión intestada; y, en otros casos se han suavizado los efectos del sistema foral, como por ejemplo en materia de troncalidad, cuando se elimina el derecho de saca foral de las zonas urbanas o urbanizables, para no extremar las diferencias entre villas y anteiglesias. El territorio foral se mantiene inamovible evitando la constante movilidad impuesta por la Compilación y la única ampliación posible que se prevé es a través del ejercicio de la opción colectiva que regula el artículo 10 de la ley, que, en definitiva pretende introducir claridad y no afectar a los derechos adquiridos.

\section{Conflictos de leyes en materia de troncalidad}

La troncalidad en Vizcaya es, según Chalbaud (Luis Chalbaud y Errazquin, La troncalidad en Vizcaya, Bilbao 1898, p. 17), «una ligadura que se establece entre la propiedad raíz y la familia que la posee para que nunca salga de ella». La ligadura es tan fuerte que no es posible hacer donación de los bienes raíces ni dejarlos en herencia, con testamento o sin él, ni siquiera permutarlos o venderlos si no es dentro de la familia troncal, o, al menos, como en el caso de las enajenaciones inter vivos, haciendo un previo ofrecimiento a la familia.

Esta idea vizcaína de la troncalidad resulta desmesurada a los ojos de los juristas foráneos que, de ordinario, relacionan la troncalidad con la sucesión intestada, no con otros modos de transmisión. No debe sorprender que Braga da Cruz, autor del mejor estudio sobre el tema, sostuviera que la troncalidad vizcaína está fuera de los límites propios de esta institución, porque la troncalidad ha aparecido en el espacio y en el tiempo en unas formas muy definidas ${ }^{4}$. Y ciertamente, las ideas sobre troncalidad en Vizcaya avanzaron en el sentido de reforzarla y ampliarla de un modo que no se conoce en otros lugares, especialmente cuando el Fuero de 1452 (capítulo CXII) declaró raíces troncales los bienes comprados a extraños, haciendo tronqueros a los hijos y descendientes.

La troncalidad así concebida es seguramente la institución que exige a los juristas vascos una mayor reflexión, no solamente acerca de su naturaleza sino también en su acomodación a la sociedad actual. Se encuentra muy arraigada en la población vizcaína, pero ello no impide que pueda acometerse una evolución, incluso buscando en ella un sentido más moderno.

\footnotetext{
${ }^{4}$ Guilherme Braga da Cruz, O direito de troncalidade, tomo I, p. 18.
} 
Entretanto, el nuevo texto foral se ha limitado a introducir algunas atenuaciones al derecho de saca foral, que es la manifestación más problemática de la propiedad troncal, reduciendo el plazo para su ejercicio a tres meses y eliminándolo de las zonas urbanas o urbanizables, para evitar su utilización con fines meramente especulativos.

Lo que no puede negarse es que la troncalidad es una institución concebida para reforzar la familia vizcaína, una familia extensa que llega hasta el cuarto grado de la línea colateral, limitación de grado que quedó ya fijada en el Fuero de 1452 (capítulo LXXXV).

La territorialidad se considera esencial para el mantenimiento de esta familia. La troncalidad no debiera quedar a merced de un cambio de vecindad del propietario que al adquirir vecindad o nacionalidad en tierra extraña haría inaplicable la troncalidad, de seguirse el principio de la ley personal.

Por eso el Fuero de 1526 reclama ya la aplicación de un principio de territorialidad, al establecer en la Ley XV del Título XX que «los vecinos de las villas que tuvieran bienes en la Tierra Llana guarden el Fuero en disponer de ellos». Naturalmente que el Fuero solamente podía referirse a los vizcaínos, pues son los únicos a los que se extendía su jurisdicción, pero es evidente el propósito de crear un sistema de territorialidad; pues no es coherente la exigencia de una doble conexión, la vecindad y la ley del territorio.

En todos los sistemas de conflictos de leyes se aplica a cada supuesto un único punto de conexión; no conozco ninguna legislación que exija la concurrencia de dos conexiones como ocurre si exigimos en Vizcaya la concurrencia de la ley personal (vecindad) con la lex rei sitae (situación de los bienes troncales en la Tierra Llana).

Y así lo entendió el Tribunal Supremo en la sentencia de 8 de junio 1874 , en la que se trataba de la sucesión de una señora vecina de Madrid que poseía una finca en Lejona (Vizcaya). El Tribunal Supremo declaró que tratándose de una finca sita en Vizcaya «sea la que quiera la naturaleza y domicilio de la testadora, no tenía facultad para disponer de la misma finca sino con sujeción a las leyes del país en que radica».

\section{El Código Civil}

El Código Civil, en su primera edición, dedicaba el artículo 10 a determinar la ley aplicable y declaraba que los bienes inmuebles «están sujetos a las leyes del país en que están sitos»; pero, a continuación, en el párrafo segundo añadía que «sin embargo, las sucesiones legítimas y las testamentarias, así respecto al orden de suceder como a la cuantía de los derechos sucesorios y validez intrínseca de sus disposiciones se regula- 
rán por la ley nacional (en nuestro caso la regional) de la persona de que se trate, cualesquiera que sean la naturaleza de los bienes y el país en que se encuentren».

Esta importantísima excepción, que aplicaba en las sucesiones la ley personal del propietario, privaba de efectos a la Ley XV del Título XX del Fuero y permitía romper el principio de troncalidad.

Los diputados vizcaínos pusieron de relieve que el párrafo segundo derogaba en parte la legislación vizcaína porque conforme al Fuero «regirá la legislación foral tratándose de bienes inmuebles, pertenezca o no a territorio aforado el que dispone» (intervención del Sr. Zavala).

No parece que la Comisión del Congreso interpretara bien estas palabras, a juzgar por la confusa respuesta del Sr. Paso y Delgado, pero es lo cierto que en la segunda edición del Código Civil se añadió al artículo 10 un tercer párrafo que decía: «Los vizcaínos, aunque residan en las villas, seguirán sometidos, en cuanto a los bienes que posean en la Tierra llana, a la Ley XV del Título XX del Fuero de Vizcaya.»

Este texto ha dado lugar a muchos comentarios e incluso fue el motivo de mi tesis, pero conviene destacar que, por primera vez, impone la doble conexión en materia de conflictos porque:

a) Aplica la ley foral exclusivamente a los vizcaínos, aunque residan en las villas (conexión personal).

b) Se aplica exclusivamente «a los bienes que posean en la Tierra Llana» (conexión real). Hay que aclarar que no todos los bienes están sometidos a esta norma sino exclusivamente los bienes troncales como resulta de la referencia a la ley XV del Título XX. En definitiva, se inicia el sistema de doble conexión en materia de troncalidad.

El párrafo 1. ${ }^{\circ}$ del artículo 10 salvaba el principio de troncalidad pero solamente cuando el titular es vizcaíno, vecino de villa o de anteiglesia. Esto daba lugar a que se pudiera hablar de dos vecindades en Vizcaya: la vecindad de los aforados, y la de los vecinos de villa, sometidos en principio al Código Civil pero sujetos al Fuero en cuanto a los bienes que poseyeran en la Tierra Llana.

Si el titular de los bienes se avecindaba en Alava o Burgos, el párrafo tercero le liberaba de las limitaciones de la troncalidad. Esto resulta muy frecuente por la facilidad de tales cambios de vecindad.

La salvaguarda del Fuero parecía exigir la admisión plena del principio de territorialidad troncal. La Comisión que redactó el Proyecto de apéndice así lo entendió cuando «habiendo parientes tronqueros» acordó dar carácter territorial a la troncalidad «sea cual fuere la nacionalidad del propietario o su vecindad» (art. 13 del proyecto). 
«Habiendo parientes tronqueros», en esta frase se encuentra el verdadero sentido de la institución troncal, que no está concebida para defender la tierra ni la propiedad, sino la familia. La troncalidad es la ley de la familia, y no tiene sentido si no hay familia, si no hay parientes tronqueros. Vincular con normas troncales a un eventual comprador que adquiere una finca desde mil kilómetros de distancia, carece de sentido.

Pero la dogmática jurídica no ha conseguido definir la familia sino de forma vaga y general. Ninguna legislación la toma como punto de conexión. La familia no es una persona jurídica ni tiene obligaciones y derechos y así es imposible ponerla en el centro de la referencia troncal. Y, sin embargo, nos hubiera ayudado mucho partir del concepto de familia para regular la aplicación de las leyes troncales.

\section{Evolución posterior}

La Compilación de Vizcaya y Alava de 30 de julio 1959 proclama de forma muy moderada el principio de territorialidad en su artículo 10 que dice: «Los vizcaínos, aunque residan en territorio distinto del foral de Vizcaya, si hubiere parientes tronqueros, sólo podrán disponer a título gratuito inter vivos o mortis causa de los bienes troncales en favor de aquellos.»

La Compilación incluye este artículo entre las normas sobre troncalidad, lo que es un evidente acierto. Y también lo fue el inciso «si hubiere parientes tronqueros», que pretende ser una referencia a la familia troncal que ya formuló el proyecto de apéndice foral desde 1900.

Pese a todo, la expresión es equívoca porque no permite determinar quiénes son los parientes tronqueros, fuera de la abstracta enumeración del artículo 7 de la propia Compilación que deja sin resolver cuestiones importantes, por ejemplo, si el pariente de un vizcaíno que adquiere vecindad en Guipúzcoa o en Alava sigue siendo tronquero. Si la respuesta es negativa, se descubre un fácil procedimiento de burlar la troncalidad.

Por otra parte, el artículo 10 solamente se aplica a los actos de disposición a título gratuito. Cuando se trata de actos a título oneroso, por ejemplo en las ventas sujetas al derecho de saca, habrá que recurrir a otras normas y hasta la reforma del Código Civil en 1973 podía pensarse que quedarían estos actos sujetos al Fuero por aplicación del párrafo tercero del artículo 10.

El párrafo tercero desapareció en la reforma del título preliminar que, no obstante, reformó el artículo 10 del C.C. para declarar que «la posesión, la propiedad y los demás derechos sobre bienes inmuebles, así como su publicidad, se regirán por la ley del lugar en que se hallen». 
Si consideramos el derecho de troncalidad como una regulación de la propiedad, el artículo 10 consagraría el principio de territorialidad, lex rei sitae, y concretamente en cuanto al derecho de saca, si estimamos que se trata de un derecho real de adquisición preferente, con arreglo al artículo 10 deberá ser aplicado cuando se trate de bienes sitos en Vizcaya.

No obstante es difícil entender que la troncalidad alcance a una persona sin ninguna conexión con Vizcaya por el hecho de haber adquirido una finca con fines puramente especulativos.

El artículo 10 de la Compilación dejaba también sin determinar la ley aplicable a la sucesión intestada.

\section{La triple conexión}

El problema conflictual se agrava a partir de la sentencia del Tribunal Supremo de 6 de marzo de 1965 en la que se sostiene que «los derechos que concede y obligaciones que impone el Fuero de Vizcaya ha de entenderse que son peculiares de los vizcaínos aforados, quienes por tal carácter disfrutan de los primeros y, por regla general, al cumplimiento de las segundas se hallan sujetos, sin que quienes no gocen de él, por estar sometidos a la legislación común, puedan conseguir el reconocimiento de derechos fundándose en una institución foral privilegiada». Como consecuencia de esta doctrina, el Supremo denegó el derecho de saca a un vizcaíno vecino de Bilbao, villa no aforada.

No es admisible el carácter de privilegio que la sentencia asigna a la ley vizcaína. La ley foral no es un privilegio sino una ley general dentro del territorio aforado. Una vez fijado su ámbito de aplicación debe favorecer y perjudicar a todos aquellos a quienes afecta, sin privilegios, sin favorecer a los vizcaínos a costa de quienes no lo son.

Si nos basamos en el criterio de la sentencia, un vizcaíno que tenga dos hijos, si uno de ellos se avecinda en Bilbao (o en Segovia) deberá dejar todos los bienes troncales a quien conserva la vecindad, único que podría ser heredero tronquero.

La sentencia instaura un sistema inédito en el campo de los conflictos de leyes, el de la triple conexión, porque:

a) Exige que la finca esté situada en tierra aforada (lex rei sitae, primera conexión).

b) El enajenante o titular de los bienes debe ser también aforado, o al menos vizcaíno (segunda conexión, ley personal del transmitente). Y

c) Quien pretende adquirir la finca ha de ser también vizcaíno aforado (tercera conexión, ley personal del adquirente). 
No creo que exista en el Derecho Internacional un sistema tan endiablado de solucionar los conflictos ni tantas barreras a la aplicación de la ley de un país.

Y ciertamente la tesis de esta sentencia ha producido consecuencias insólitas como, por ejemplo, la declaración de nulidad de una donación a una hija por tener nacionalidad norteamericana, por lo que no podía ser donataria.

\section{La troncalidad en la Ley Civil Foral vasca}

La preparación de la ley de Derecho Civil Foral presentaba, aunque sorprenda, mayores dificultades al Parlamento Vasco que las que tuvieron las Cortes españolas para aprobar las Compilaciones, porque éstas tenían la plenitud del poder legislativo y pudieron disponer a su arbitrio respecto del ámbito de aplicación de las leyes forales, cuestión capital en el Derecho civil vasco.

La Constitución de 1978 también concede unos amplios poderes a las Comunidades Autónomas, pero con unas limitaciones expresas, entre las cuales hay que destacar la reserva al Estado de la competencia para dictar «normas para resolver los conflictos de leyes» (art. 149.1.8).

Con esta limitación se hacía difícil reproducir, incluso modificado, el artículo 10 de la Compilación, que evidentemente es una norma de conflicto, y como tal la incluyó el Código Civil en su artículo 10.

El Estatuto de Autonomía, no obstante, concedía a la Comunidad Autónoma la facultad de fijar el ámbito de aplicación del Derecho Foral (art. 10.5). Esta facultad no supone la solución de conflictos de leyes (que no hubiera podido ser cedida a la Comunidad Autónoma) sino la posibilidad de hacer una determinación territorial que es competencia del Estado, pero que el artículo 149 no le atribuye en exclusiva por lo que pudo ser asumida por el País Vasco en virtud de su correspondiente Estatuto (art. 149.3) especialmente si se trata, como en el caso vasco, de la delimitación de zonas territoriales dentro de la propia Comunidad Autónoma. Es impensable que las Cortes Generales decidan acometer esta delimitación de ámbitos.

Me parece inadmisible la opinión de quienes han sostenido que el artículo 10.5 del Estatuto permite a la Comunidad reducir el ámbito del Derecho Foral pero no ampliarlo, porque el ámbito del Derecho común es intocable, tesis que también sostuvo el recurso del Gobierno.

Sin embargo, la Comisión redactora del proyecto no estimó prudente hacer modificaciones territoriales en una materia que tanto afecta a los intereses de los particulares y se limitó a dar estabilidad a la situación territorial existente, para lo que, no solamente se mantuvo el 
Derecho común en las villas designadas en la Compilación sino que incluso, para resolver las dificultades que siempre ha planteado la distinción entre zona aforada y no aforada dentro de las mismas villas, se quisieron dejar los límites clara y definitivamente determinados por medio de planos que deberían confeccionar los ayuntamientos (disposición adicional $1^{a}$ ). Y también en el valle de Ayala se mantuvo el ámbito de aplicación fijado en la Compilación, con la única ampliación a Arrastaria, que, de otra forma, constituiría un extraño enclave de Derecho común.

Era convicción general la de que el estatuto civil de una persona no debía ser sustancialmente alterado por el legislador sin graves razones para ello.

No obstante, la Comisión entendió que había que hacer un esfuerzo de aproximación entre las dos legislaciones vigentes en Vizcaya, y a ello se tendió por dos caminos: por un lado, se aminoró la distancia entre la legislación común y la foral mediante decisiones muy variadas, limitando la legítima de los ascendientes (art. 56) haciendo una regulación de la legítima vidual muy similar al Código Civil (art. 58) y lo mismo en la sucesión intestada (arts. 69 a 72) y reservando el derecho de saca exclusivamente para las zonas rurales (art. 114), etc.

Por otra parte, se pensó también en aproximar el derecho común aplicable a los vecinos de las villas al sistema foral, pero no trasladando de golpe el Fuero a las villas, lo que resultaría insoportable violencia, sino valiéndonos de la competencia vasca para fijar el ámbito territorial de vigencia aplicándola, no ya al Fuero en su totalidad sino a un limitado número de instituciones, lo que parece perfectamente factible, además de aconsejable, a la vista del artículo 10.5 del Estatuto.

No parecía conveniente extender a las villas las instituciones de carácter imperativo y limitativas de derechos que podían resultar muy onerosas para los habituados a un sistema distinto, como sucede con la troncalidad en general. En cambio, se estimó oportuno extender a las villas algunas instituciones que suponen un incremento de libertad y ninguna imposición, libertad negada en el Código Civil. Con esta idea se redactó el artículo 13 que permite a los vecinos de villa otorgar testamento mancomunado y por comisario.

A las razones antes apuntadas, que aconsejaban la aproximación sin violencias de las dos legislaciones, se añadía en cuanto a las formas del testamento, el hecho de haberse introducido en la legislación común la posibilidad de una doble vecindad en el matrimonio, lo que, en muchos casos, hacía difícil o imposible a los aforados la utilización de esas formas de testar basadas en la confianza entre los cónyuges y en la necesidad de disponer conjuntamente de los bienes comunes. 
En definitiva, la Ley Foral hace una regulación muy equilibrada de las dos formas de vecindad en Vizcaya en forma que permite su evolución futura hacia una mayor unidad. Ello no fue obstáculo que impidiera al Gobierno la formulación de un recurso contra este artículo 13, entre otros.

Se alegaba que este artículo, en combinación con el 6 y el 11, de la nueva Ley de Derecho Civil Foral venía a crear una doble vecindad en Vizcaya, la de los aforados y la de los no aforados; pero, como dijo el dictamen del Consejo de Estado, una norma foral aplicable a los vizcaínos no aforados no es una novedad en el Derecho Civil vizcaíno pues el artículo 10 de la Compilación también se aplicaba a los no aforados, así como el párrafo tercero del artículo 10 del Código Civil.

Retirado el recurso, el artículo 13 quedó en plena vigencia.

\section{La aplicación de la troncalidad en la nueva ley foral}

\section{El artículo 17 de la nueva ley Civil foral}

Puesto que el Parlamento Vasco no tenía competencias para regular los conflictos de leyes, convenía buscar una fórmula que preservase el principio de territorialidad en materia troncal, sin cuyo requisito esta institución carecería de sentido.

Este es el efecto que persigue el artículo 17.4 cuando comienza afirmando que «la propiedad de los bienes raíces es troncal». Dado que «la posesión, la propiedad y los demás derechos sobre bienes inmuebles, así como su publicidad» se rigen por la ley del lugar en que se hallen (art. 10 del C.C.), la troncalidad en Vizcaya, cualidad esencial de la propiedad, se ha de aplicar siempre que se trate de bienes sitos en Vizcaya.

Así queda garantizada la aplicación de las leyes troncales a vizcaínos y no vizcaínos. Ello es evidente respecto de todos los actos de disposición inter vivos, la donación o la venta, porque los actos en sí mismos puedan revestir cualquiera de las formas que autoriza el artículo 11 del C.C. y establecer toda clase de cláusulas y pactos, pero los derechos troncales, como la saca foral o el derecho a impugnar las donaciones, al recaer sobre bienes inmuebles sitos en Vizcaya, deben ser regidos por la ley foral como lex rei sitae (art. 10).

El artículo 10 del C.C. ni siquiera exige que los derechos sobre inmuebles sean «derechos reales» para aplicar el principio de territorialidad, aunque los derechos citados recaen sobre inmuebles y tienden a la conservación de los bienes en la familia troncal. Pese a ello, no dejan de plantearse otras cuestiones conflictivas especialmente en materia de sucesiones. 
Lo que el artículo 17 de la ley foral pretende es mantener firmemente el cáracter familiar de estos derechos, y así lo determina claramente cuando en el mismo primer párrafo añade que «a través de la troncalidad se protege el carácter familiar del patrimonio». Se ha elegido el camino de la territorialidad, pero no oculta su propósito de proteger la familia, la realidad básica de la ley vizcaína que la ley no considera como punto de conexión. Y este es un dato que no puede dejar de ser considerado en la interpretación de la ley foral, especialmente si se tiene en cuenta que el artículo 17.2 proclama los efectos de la troncalidad cuando dice:

«2. En virtud de la troncalidad, el titular de los bienes raíces solamente puede disponer de los mismos respetando los derechos de los parientes tronqueros.»

La troncalidad no es un beneficio personal para el titular de los bienes, que no es sino el cabeza de la familia troncal, y en todos sus actos debe dar preferencia a la familia. Y, por ello el artículo 17 termina añadiendo:

«Los actos de disposición que vulneren los derechos de los parientes tronqueros podrán ser impugnados en la forma y con los efectos que se establecen en el presente Fuero Civil» (art. 17.3).

Más adelante volveré a ocuparme de los problemas que estos preceptos plantean.

\section{El fin de la triple conexión}

Aplicando el principio de territorialidad se pone fin a la teoría que brota de las sentencias del Tribunal Supremo que elevaban al máximo las dificultades para la aplicación del Fuero de Vizcaya, exigiendo no solamente que la finca estuviera situada en Vizcaya sino también que fuera vizcaíno el transmitente y también lo fuera el adquirente. Esta doctrina rompía la unidad familiar al hacer a algunos de sus miembros de distinta condición que otros, pues si alguien se avecindaba en las villas perdía toda opción a los bienes troncales.

Si la troncalidad se aplica siempre que los bienes estén sitos en Vizcaya, los derechos y obligaciones que nacen del Fuero no son exclusivos de los vizcaínos, del mismo modo que no son exclusivos de los españoles los derechos que nacen del Código Civil, pues nadie impide que un hijo nacionalizado extranjero pueda reclamar el derecho de heredar a su padre.

4 Adrián Celaya Ibarra, Vizcaya y su Fuero Civil, Pamploma 1965. 
No obstante, la aplicación amplia de este principio podía llevar a conclusiones excesivas, no deseadas por los redactores de la Ley Foral, porque dado el carácter imperativo y, al mismo tiempo, limitativo de la libre disposición que tiene la troncalidad resulta excesivo imponerla a quien nunca ha tenido una conexión con la Tierra Llana de Vizcaya. El forastero que, quizá a través de una agencia, adquiere una finca en Vizcaya, no parece que deba quedar sometido a tales limitaciones.

Al mismo tiempo se plantea otro problema con las sucesiones mortis causa, porque conforme al artículo 9.1 del Código Civil la ley personal es la que rige la sucesión por causa de muerte. Es cierto que esta regla no aparece como una excepción a la territorialidad, como en el artículo 10 de la edición del Código de 1888, pero se trata de una norma autónoma que parece debe tener prevalencia. Y esto nos puede llevar a la anomalía de que se pudiera hacer por un acto mortis causa lo que está prohibido inter vivos.

\section{El artículo 23}

Había que evitar la excesiva expansión de la troncalidad y, al mismo tiempo, mantener viva la sucesión troncal cuando se trata de una familia vizcaína, y a estos efectos se elaboró el artículo 23 de la nueva Ley Civil Foral, que dice:

«Artículo 23. Los derechos y obligaciones derivados de la troncalidad corresponden, como vizcaínos, a todos los que tengan vecindad civil en Vizcaya.

Por esencia de la troncalidad, la pérdida de la vecindad vizcaína no supone restricción alguna en los derechos y deberes de cualquier naturaleza derivados de la misma.»

Pesaba en los redactores la sentencia del T.S. de 6 de marzo de 1965 que afirmaba que los derechos y obligaciones del Derecho vizcaíno solamente corresponden a los vizcaínos aforados, de donde se podía extraer la extraña consecuencia de que el que no fuera aforado o no fuera vizcaíno no podía ni siquiera suceder a un aforado. El texto actual pretende evitar esta limitación haciendo que todos los vizcaínos tengan derecho a disfrutar de los derechos y estén sujetos a las obligaciones que el Fuero impone.

Desde el punto de vista de los derechos se quiere evitar que pueda producirse un caso similar al analizado en aquella sentencia, esto es, que por haberse avecindado en una villa pierda un vizcaíno su derecho a la saca (o a la sucesión) mientras sus parientes, sus hermanos o primos lo 
conservan. Pero era necesario también evitar que por la pérdida de la vecindad vizcaína o acaso de la nacionalidad pueda una persona ser privada de los derechos familiares que nacen de la troncalidad; y con este criterio se redactó el párrafo segundo del artículo 23. Un vizcaíno conserva, en virtud de este texto, los derechos originarios que le vinculan con la casa de sus mayores, aunque pierda su vecindad. Entiéndase bien que esta situación no se transmite, por lo que, por supuesto, quienes nunca han sido vizcaínos carecen de estos derechos que no se conservan de generación en generación. Naturalmente que estamos hablando de derechos de troncalidad, cuyo ámbito se limita a la familia vizcaína, y que se aplica en materia sucesoria sobre unos bienes muy determinados, y desaparece cuando se va más allá del cuarto grado.

Y lo mismo hay que decir de las obligaciones, pues sería un fraude a la ley vizcaína que el titular de los bienes troncales pudiera burlar sus deberes por el simple hecho de cambiar de vecindad.

En realidad, el artículo 23 se propone limitar la territorialidad absoluta que podría derivarse de la aplicación general del artículo 17.

Se trata de una limitación del principio de territorialidad troncal que no puede ir más allá de donde llega la familia troncal. El artículo 23 no fue recurrido por el Gobierno.

\section{Segunda Parte: Vecinos de villa y anteiglesia}

Los orígenes de Vizcaya se remontan, cuando menos, al siglo IX según el cronicón salmanticense del obispo D. Sebastián. De aquellos remotos tiempos las noticias son escasas y están envueltas en la leyenda, de la cual lentamente van saliendo los Señores de Vizcaya y aparecen con colores cada vez más nítidos, moviéndose primero alrededor del reino de Navarra y más tarde de la Corte de Castilla hasta llegar en 1379 a asumir el trono castellano.

Cual fuera el régimen jurídico vigente en Vizcaya durante la Edad Media es difícil de adivinar, especialmente en materia civil, por la falta de documentos, pero es lo cierto que mientras en toda España se otorgaban Fueros Municipales ${ }^{6}$ en Vizcaya no se otorgó ninguno hasta el siglo XIII.

Sin embargo, a partir de este siglo, los Señores de Vizcaya crean hasta veintiún villas a las que conceden Fueros, empezando por Ber-

6 Castrojeriz (974), León (1020), Toledo (1118), Nájera (1076), Logroño (1095), San Sebastián (1150), Vitoria (1181), Daroca (1146), etc. 
meo $(1237)^{7}$ hasta llegar a las fundadas por el infante D. Juan que luego se convirtió en Juan I de Castilla ${ }^{8}$. Los Señores de Vizcaya mostraban con estos otorgamientos el alcance de su poder, pues algunos historiadores consideran que la potestad de fundar villas corresponde al monarca $o$ a persona en quien delegue y no consta que, en ningún caso, obraran los Señores por delegación.

\section{Régimen civil de las villas}

Son muy pocas las disposiciones civiles que aparecen en estos Fueros, aunque en general se remiten al Fuero de Logroño (o al de Vitoria, que también depende del Fuero de Logroño) pero es preciso tener en cuenta que en la Alta Edad Media el Derecho Civil que se aplica no depende, en general, de textos escritos, pues se va elaborando a través de usos y costumbres que, en el mejor de los casos, se recogen en colecciones particulares como ocurre probablemente con el que es conocido como Fuero de los labradores de Durango.

A partir de la publicación del Fuero Real va extendiéndose en Castilla la legislación escrita, y ya en el Fuero de Miravalles encontramos la disposición de que se ponga en vigor en la villa el Ordenamiento de Alcalá, por lo que evidentemente las villas vizcaínas introducen en sus términos la legislación castellana.

Por otra parte, parece clara la pretensión de los Señores de dejar «villada» o constituida en villa casi toda Vizcaya, pues los términos que se conceden a las villas son tan amplios que, en la mayor parte de los casos llegan hasta el límite de las villas vecinas ${ }^{9}$. Sin embargo, es un hecho comprobado que las diversas anteiglesias de Vizcaya continuaron rigiéndose por usos y costumbres propias, y el Derecho común solamente penetró en el territorio de las villas. Incluso pudo entenderse que el Dere-

7 La villa de Valmaseda fue fundada en 1199, pero cuando no pertenecía a Vizcaya y la ciudad de Orduña es fundación de la que no consta fecha, pero el Fuero le fue concedido en 1229 por D. Lope Díaz de Haro.

${ }^{8}$ Por orden de antigüedad las villas de Vizcaya son las siguientes: Valmaseda, fundada en 1199, cuando no pertenecía a Vizcaya, Orduña con Fuero de 1229, Bermeo en 1236, Lanestosa en 1287, Plencia, en 1299, Bilbao en 1300, Ochandiano en 1304, Portugalete en 1322, Lequeitio en 1325, Ondárroa en 1327, Villaro en 1338, Marquina en 1355, Elorrio, en 1356, Guernica en 1366, Guerricaiz en 1366, Durango cuyo Fuero fue confirmado en 1372 pero su fundación por los reyes de Navarra debe ser muy antigua, Ermua en 1372, Miravalles en 1375, Munguía en 1376, Larrabezúa en 1376 y Rigoitia en el mismo año 1376. No consta la fecha de creación de la ciudad de Orduña, cuando aún no pertenecía al Señorío.

9 Es muy ilustrativa la extensión que se da a la villa de Bilbao en su carta de fundación, que asume incluso las anteiglesias vecinas, y además en una concesión posterior de Enrique I le agrega las anteiglesias de Arrigorriaga, Zarátamo y Galdácano (v. Labayru, tomo II, p. 848). 
cho común nunca rigió fuera del casco o parte cercada de las villas como sostiene $\mathrm{Jado}^{10}$.

De hecho, la creación de villas determinó la coexistencia en Vizcaya de dos legislaciones distintas con límites imprecisos que siempre ha sido trabajoso definir.

\section{La ley civil de las villas y anteiglesias}

Penetró el Derecho común en las villas de Vizcaya, pero, al contrario de lo que ocurre en Guipúzcoa, no lo hizo en el resto del Señorío, que mantuvo sus propios usos y costumbres, formados espontáneamente al margen de toda legislación. Las anteiglesias que las Cartas pueblas integraban en las villas recuperaron su autonomía y continuaron gobernándose por sus propios y tradicionales usos. Si hubo un intento de dividir toda Vizcaya en villas evidentemente fracasó.

No es fácil conocer las viejas costumbres de las anteiglesias vizcaínas, aunque es muy probable que algunos de los viejos usos se recogieran en dichos o refranes populares que, naturalmente se formularían en lengua vasca como en el ejemplo que aparece en el Fuero Viejo ${ }^{11}$, pero no parece verosímil que hubiera una colección de Fueros escritos en euskera como afirmó Iñiguez de Ibargüen.

En cambio, tenemos un buen ejemplo de colección de costumbres en el conocido como Fuero antiguo de la merindad de Durango que Labayru recogió en el tomo II de su Historia de Vizcaya. En este texto apuntan ya las instituciones civiles más importantes del Derecho vizcaíno, expresadas en lengua castellana.

Lo que en la historia del Derecho vizcaíno resulta determinante para su futuro es la aprobación del Fuero de 1452, al que suele tacharse de falta de método o sistema (muy normal en textos medievales) pero que deja plasmadas en su texto las instituciones básicas de Vizcaya, tal como estaban vigentes en su época, e introduce algunas modificaciones, aunque, en esencia, mantiene las líneas básicas de los usos comunes.

El Fuero Viejo es un texto de aplicación general en el Señorío de Vizcaya por lo que se expresa en términos generales, declarando repetidas veces que se refiere a los vizcaínos «así de las villas como de la tie-

10 Rodrigo Jado y Ventades, Derecho Civil de Vizcaya, p. 14

11 En el capítulo XC del Fuero Viejo, según la edición de Astuy, se dice textualmente que «el Fuero de Vizcaya antiguo manda urde urdaondo caecia etondo», texto que no demuestra la existencia de un Fuero antiguo escrito (máxime cuando en el preámbulo se dice que los Fueros de Vizcaya no estaban escritos) pero, en cambio, da fe de una sentencia euskérica que ha dado lugar a diversas interpretaciones, aunque su sentido se infiere del contexto. Y por supuesto, esa sentencia no es la única. 
rra llana de Vizcaya, durangueses é de las Encartaciones...» (por ejemplo en el capítulo $\mathrm{X}$ de Astuy). Las normas civiles no distinguen y podría entenderse que son aplicables a todos los vizcaínos sin excepción. No obstante, su carácter rural, las referencias a «heredades» cuando se trata de bienes troncales, etc., no parecen pensadas para los vecinos de villa. Por otra parte, parece claro que las Encartaciones siguieron rigiéndose por sus propias normas civiles que mantienen peculiaridades importantes.

Es probable que las costumbres en la villa y en la anteiglesia no fueran en aquella época muy diferentes, si se tiene en cuenta que en el Fuero Real se permitían los poderes testatorios y los pactos para suceder y que marinos y mercaderes se rigieron por usos propios, especialmente desde que comenzó a funcionar el Consulado de Bilbao. En las Cartas Pueblas de las villas las normas civiles son escasas y se refieren, por lo general, a la contratación en los mercados, con alguna excepción, como el Fuero de Bermeo que recoge la prescripción de año y día (institución que también pasó al Fuero).

Hay que suponer que la separación de las villas en materia civil se acentuaría a partir del año 1487 y las Ordenanzas de Chinchilla, que motivaron una profunda escisión acordando las villas no concurrir a las Juntas de Guernica, decisión que mantuvieron durante más de un siglo.

\section{El Fuero de 1526}

Pese a todo, el Fuero de 1526 sigue refiriéndose genéricamente a todos los vizcaínos, sin excepción y es indudable que sus normas se aplicaron con carácter general en materia de Derecho Público (la declaración de hidalguía universal es el ejemplo más notorio); pero en el campo del Derecho Privado, aunque no exista una excepción expresa, parece claro que hay una legislación diferente para las villas, como se desprende de la Ley XV del título XX. Dice esta Ley:

«Ley XV. Que los vecinos de las villas que tuvieren bienes en la Tierra Llana guarden el Fuero en disponer de ellos.

»Otrosí dixeron: Que habían de Fuero, y establecían por Ley, porque acaece que algún vecino de las villas de Vizcaya entre otras tierras y heredades, que tienen sitas en el juzgado de la tal villa, de donde es, tiene y posee otras tierras y heredades sitas en el Juzgado y Tierra Llana y así troncales: y acaece que el tal suele disponer de las tales tierras por sí o a vueltas con las otras heredades de la tal villa, agora en vida, agora en muerte: Y ponen duda de si de los tales bienes troncales ha de disponer según que de los otros que no son troncales. Por ende dixeron: Que ordenaban y ordenaron que el tal vecino de villa, do los bienes (según ley del reino) son partibles; que toda la tal raíz que tuviere en la tierra llana y 
juzgado de Vizcaya sea de la condición y calidad, privilegio y fuero que la otra raíz que posean los vizcaínos de la tierra llana troncal: y tal que en vida y en muerte pueda disponer de ello como podía disponer el vizcaíno, vecino de la tierra llana: y sean admitidos para la tal raíz los tronqueros profincos, como y según se admiten a los bienes que poseen, venden y mandan los vizcaínos vecinos de la Tierra Llana.»

De esta ley se ha sacado la conclusión de que existen dos vizcainías:

a) La del vecino de la Tierra Llana, vizcaíno aforado o infanzón, sujeto en todos sus términos a las leyes forales,

b) La de los vecinos de villa o no aforados, sometidos al Derecho común, que, no obstante, tienen que someterse a las prescripciones del Fuero respecto de los bienes que poseen en la Tierra Llana.

Esta peculiaridad de los vecinos de villa deja de ser tal para convertirse en una simple manifestación del principio de territorialidad si tenemos en cuenta que la misma doctrina (la obligación de respetar los bienes troncales) se aplica cuando los dueños de bienes raíces son personas ajenas al Señorío. Quizá los redactores del Fuero no aludieron a ellos porque, aparte de no ser personas sometidas a la autoridad de las Juntas Generales, el supuesto se daba con menos frecuencia.

Lo cierto es que antes de la publicación del Código Civil se aplicaba la troncalidad vizcaína a todas las personas que tuvieran bienes raíces en la Tierra Llana, como resulta de la sent. del T.S. de 8 de junio de 1874. Se trataba de la sucesión de una señora, natural y vecina de Madrid, que había nombrado heredero universal a quien no era un pariente tronquero, al menos respecto de una finca sita en Lejona y que formaba parte del patrimonio hereditario. El testamento fue impugnado y el Tribunal Supremo declaró que «los bienes sitos en Vizcaya han de regirse para las sucesiones por las leyes forales, toda vez que existen parientes vizcaínos que tienen notorio derecho a la sucesión».

El mismo criterio de territorialidad se reafirma en la Res. de la D.G. de los Registros de 24 de abril de $1883^{12}$ que después de declarar que «las fincas objeto de la escritura de aceptación otorgada por D. ${ }^{a}$ B.B. por radicar fuera de las villas de Vizcaya, o sea en el Infanzonado, son de naturaleza troncal y tales que, según el privilegio o Fuero de la Tierra, el tronco vuelve al tronco y la raíz a la raíz», denegó la inscripción porque la solicitante «no era pariente tronquera ni se le llama tal en ninguno de los documentos presentados».

12 Pueden verse estas resoluciones en mi libro Vizcaya y su Fuero Civil, Aranzadi, Pamplona 1965 , p. 331. 
Sin embargo, por esta misma época el Tribunal Supremo había ya afirmado para otros territorios españoles el principio de la aplicación de la ley personal en materia de sucesiones. Decía la sentencia de 27 de noviembre de 1868 que «la ley personal de cada individuo es la del país a que pertenece, la cual le sigue dondequiera que se traslade, regulando sus derechos personales, su capacidad de trasmitir por testamento o abintestato y el régimen económico de su matrimonio y familia».

En esta época no existia una normativa legal sobre los conflictos de leyes, por lo que la doctrina del Tribunal Supremo se basa en las ideas jurídicas que dominaban en su momento que se inspiraban en la teoría de los estatutos y la personalidad de las leyes. No obstante, se aplicó en Vizcaya el principio de territorialidad. Era ineludible que la Codificación se ocupara de formular unas reglas de conflicto y esto colocaba al Derecho vizcaíno en una problemática difícil.

\section{El Código Civil}

El Código Civil formuló las reglas de conflicto de acuerdo con la teoría de los estatutos (personal, real y formal) al menos terminológicamente, aunque con fuerte influencia de la doctrina nacionalista de Mancini. El criterio seguido es, a mi juicio, equivocado, porque se regularon primero los conflictos de leyes en materia internacional, en los que nuestros Tribunales tenían poca experiencia e incluso durante muchos años trataron de evitar la aplicación del Derecho extranjero por los medios más inverosímiles, multiplicando los casos de excepción (orden público, reenvío, fraude a la ley, interés nacional, dificultades de prueba del derecho extranjero, etc.) y, a continuación, se estableció que las mismas reglas se aplicarían en el campo de los conflictos interregionales, lo que hacía inútil la experiencia adquirida por la jurisprudencia anterior.

Este sistema ponía en serio peligro la integridad del Derecho vizcaíno, basado en la territorialidad de las normas sobre la propiedad troncal. Si prevalecía en todo caso la ley personal, como ocurriría por la aplicación del artículo 10 que en materia de sucesiones establecía la obligatoria aplicación de la ley del causante, los vecinos de villa no estarían sujetos a la troncalidad respecto de los bienes que poseyeran en la anteiglesia. Esta disposición, en palabras del senador vizcaíno Zavala derogaba en parte la legislación civil de Vizcaya, por lo que dirigió un ruego a la Comisión codificadora.

«Se trata, decía, entiéndase bien, de un vecino de villa de Vizcaya, que posee bienes en Infanzonado. Creo que lo que procede «... es que rija para este caso concreto, la Ley XV del Título XX del Fuero de Vizcaya, que prescribe que los vecinos de villa que tienen bienes en la Tierra Llana, guarden el Fuero en disponer de ellos...». 
Si nuestra doctrina hubiera tenido un mayor desarrollo se hubiera pedido que el principio de troncalidad fuera territorial, esto es, que constituyera una excepción general al principio de personalidad de las leyes, lo que estaría en congruencia con la jurisprudencia anterior. Pidieron algo mucho más limitado y no sabemos bien si lo entendió la Comisión porque la respuesta del Sr., Paso y Delgado fue bastante oscura:

«Esto está en su lugar, decía, y es evidente por la razón sencillísima de que el fuero del estatuto personal no deroga en manera alguna el estatuto territorial. Y estando esos bienes de tierra llana enclavados en territorios especiales de fueros, es evidente que por el estatuto territorial les corresponde a sus dueños ese derecho por más que el estatuto personal pueda a los mismos dueños referirse, toda vez que viven en tierra de villas.»

Lo cierto es que en la segunda edición del Código se añadió al artículo 10 un párrafo tercero que decía:

«Los vizcaínos, aunque residan en las villas, seguirán sometidos, en cuanto a los bienes que posean en la Tierra Llana, a la Ley 15 Título XX del Fuero de Vizcaya.»

Este precepto ha sido objeto de contradictorias opiniones. Alonso Martínez lo justificaba alegando que sin esta norma se quitaba a Vizcaya la disposición con la que está más encariñada ${ }^{13}$. Pero la opinión común entre los juristas españoles veía mal el fraccionamiento de la herencia, aunque la experiencia cotidiana asistía a la realidad de este fraccionamiento en casi todos los casos de conflicto con el Derecho extranjero. El principio de la unidad de la herencia era un legado romano al que las ideas racionalistas de la época no podían oponerse.

Lo cierto, no obstante, es que el párrafo tercero subsistió hasta la reforma del Código en 1973 y la consecuencia fue que en Vizcaya hubo necesariamente que admitir la existencia de dos vizcainías, la foral, de los vecinos de anteiglesia o parte aforada de las villas y la no aforada, de los vecinos de villa.

\section{Los proyectos de Apéndice foral}

Este tema produjo opiniones encontradas en Vizcaya en la época en que, siguiendo lo ordenado por el Código Civil, se preparaba un proyecto de Apéndice. Había opiniones extremas como la de Allende

13 Manuel Alonso Martínez, Fundamentos de la doctrina de algunos preceptos del Código Civil. Madrid, 1899, p. 12. 
Salazar ${ }^{14}$ que creía que el Fuero debía aplicarse en toda Vizcaya sin excepciones hasta la de Balparda para quien el Fuero debía aplicarse solamente en los caseríos ${ }^{15}$.

La Comisión especial de Codificación de Vizcaya entendió perfectamente el carácter territorial de la troncalidad cuando en la sesión de 17 octubre 1899 acordó que fuese obligatoria la aplicación del Fuero para todo el que poseyere bienes raíces en territorio aforado, y con este criterio se redactó el proyecto de apéndice que decía:

Artículo 13. Habiendo parientes tronqueros de cualquier línea que sean, nadie podrá disponer en vida ni por causa de muerte, en favor de quien no tuviere aquel carácter, de bienes troncales algunos, sea cual fuere la nacionalidad del propietario o su vecindad. Esta prohibición se hace extensiva a la capacidad para suceder abintestato.

Esta redacción es bastante más ambiciosa que el párrafo tercero del artículo 10 del Código, pues establece la plena territorialidad, si bien limitada a los efectos de la troncalidad.

El proyecto del Colegio de Abogados de 1928 volvió al criterio del Código Civil limitando el alcance de la troncalidad a «los vizcaínos aunque residan en las villas». Del proyecto de 1900 acepta únicamente la extensión de esta norma a la sucesión intestada (art. 12).

\section{La Compilación}

La Compilación de 30 de julio de 1959 recogió la doctrina sobre esta materia en su artículo 10 que decía: «Los vizcaínos aunque residan en territorio distinto del foral de Vizcaya, si hubiere parientes tronqueros, sólo podrán disponer a título gratuito inter vivos o mortis causa de los bienes troncales en favor de aquellos.»

Las innovaciones de este artículo, aparte de su aclaración de que se refiere a bienes troncales radican, por un lado, en la precisión de que los vizcaínos no aforados quedan sujetos a Fuero aunque residan «en territorio distinto del foral de Vizcaya» y por otro, su limitación a los actos a título gratuito que pone en duda la aplicación de la troncalidad en materia de saca foral.

La Compilación planteaba numerosos problemas de los que no voy a ocuparme ahora pues los analicé extensamente en otro lugar ${ }^{16}$. Tampoco

\footnotetext{
14 Angel Allende Salazar, El dualismo en la legislación civil de Vizcaya, R.G.L.J. 1879, p. 52.

15 Gregorio Balparda y de las Herrerías, El Fuero de Vizcaya en lo civil, Bilbao 1903, p. 12.

16 Adrián Celaya Ibarra, Vizcaya y su Fuero Civil, Aranzadi, Pamplona, 1965.
} 
derogaba el párrafo tercero del artículo 10 del Código Civil, por lo que podía entenderse que la situación anterior se mantenía inalterada; pero la reforma del título preliminar en 1973 eliminó toda referencia a los vecinos de villa en Vizcaya, con lo que la única norma especial en esta materia se limitaba al artículo 10 de la Compilación.

Esta reforma del Código Civil planteó serias cuestiones que comenté en otro lugar ${ }^{17}$ y no voy a volver sobre ellas porque ya han perdido su actualidad.

\section{La Constitución de 1978}

El artículo 149.1.8. ${ }^{\circ}$ de la Constitución Española declaraba la competencia exclusiva del Estado en materia de legislación civil «sin perjuicio de la conservación, modificación y desarrollo de los Derechos civiles, forales o especiales, allí donde existan». Esta competencia foral tiene una importante limitación, pues nunca puede comprender las materias reservadas al Estado en forma absoluta que el propio precepto constitucional enumera.

Estas normas constitucionales han dado lugar a muchos comentarios y a interpretaciones muy diversas, aunque prevalece la opinión de que la existencia de una legislación histórica es un precedente necesario para la atribución de competencia en esta materia a las Comunidades Autónomas. Es decir que, si los territorios vascos no hubieran gozado de normas propias en materia de Derecho Civil, el Estatuto no les hubiera podido asignar competencia alguna en esta materia. Esto no significa que el Derecho foral haya de quedar estancado, pues como afirma el Tribunal Constitucional, no hay obstáculo para «una acción legislativa que haga posible su crecimiento orgánico» (sent. 88/1993 de 12 de marzo), aunque no falten opiniones que sostienen que las Comunidades Autónomas «no tienen limitada su competencia más allá de la reserva al Estado del inciso «En todo caso...» ${ }^{18}$.

\section{El Estatuto Vasco}

El Estatuto de Autonomía del País Vasco declara que es competencia exclusiva de la Comunidad Autónoma «la conservación, modificación y desarrollo del Derecho Civil foral y especial, escrito o consuetudinario, propio de los territorios históricos que integran el País Vasco y la fijación del ámbito territorial de su vigencia» (art. 10.5).

17 Adrián Celaya Ibarra, «Compilación de Vizcaya y Alava» en Comentarios al Código Civil y Compilaciones Forales, Editorial Revista de Derecho Privado, Madrid, 1978, pp. 118 y siguientes.

18 V. el voto particular del Magistrado D. Julio D. González Campos a la sentencia citada. 
Es importante la referencia de este artículo al Derecho consuetudinario, que hace posible legislar acerca de las costumbres guipuzcoanas, pero en relación con las villas de Vizcaya es trascendental que se reserve a la Comunidad Autónoma la facultad de fijar el ámbito de vigencia del Derecho foral.

La delimitación del territorio foral en Vizcaya es la primera cuestión que se presenta al legislador, como reconocía la Compilación de 1959, que consideraba este tema «la debilidad interna del sistema» y añadía que comprometía su «eficacia funcional» (Exposición de motivos). La Compilación dedicaba a la fijación del ámbito territorial su Título I.

Cualquier intento de legislar sin una fijación clara de los límites territoriales hubiera sido un esfuerzo baldío, y por ello era necesario atribuir al legislador autónomico la potestad de fijar el ámbito y las limitaciones con las que la ley foral se aplica.

¿A quién podía corresponder esta potestad dentro de Vizcaya? El artículo 149 no la atribuye al Estado pues no creo que pueda incluirse en el concepto de «normas para resolver los conflictos de leyes». No se plantea ningún conflicto cuando se declara simplemente el alcance territorial de los actos del legislador, definiendo lo que es tierra de infanzonado o de villa. Los conflictos surgen a partir de aquí.

Desde el punto de vista práctico resulta inconcebible que esa competencia corresponda al Estado mientras la legislación foral se elabora autonómicamente sin conocer el territorio al que se va a aplicar. Y es inverosímil que las Cortes españolas se detengan a reflexionar sobre el Derecho civil vasco y el perímetro en el que ha de aplicarse.

Y puesto que esta competencia no la reserva al Estado el artículo 149, puede perfectamente ser asumida en el Estatuto por la Comunidad Autónoma, y esto es lo que hizo el artículo 10.5 optando por la solución más razonable sin interferir en ningún momento en la competencia que corresponde al Estado para dictar normas sobre conflictos de leyes. Del mismo modo que la regulación de la nacionalidad (ésta sí reservada al Estado) no es un problema conflictual, aunque la nacionalidad constituya un importante punto de conexión, tampoco lo es la fijación del alcance territorial del Derecho Foral.

La posibilidad de fijar los límites territoriales del Fuero y del Derecho común es indispensable para elaborar una legislación civil adaptada a las necesidades de la sociedad vasca.

\section{El vecino de villa}

De todo lo expuesto se desprende la evidencia de que existen en Vizcaya dos clases de vecindad: la de los aforados o vecinos del Infanzonado o Tierra Llana y la de los no aforados, sometidos al Código Civil y vecinos de las villas. 
Es un dato que resultaba esencial al redactar la ley de Derecho Civil vasco. Pero también se presentaron otras consideraciones: por un lado, se trataba de no hacer reformas muy drásticas, pues aunque haya que hacerlas en el futuro será después de numerosos estudios y con un buen consenso social; y desde este punto de vista la ley es conservadora. De otra parte era muy razonable el deseo de no ahondar, y más bien suavizar, las diferencias entre los vizcaínos y ello exigía alguna aproximación entre las dos legislaciones vigentes. Esto se intentó procurando no trastornar la vida civil de los dos tipos de vecinos vizcaínos, los de villa y los de anteiglesia, y por esto la ley supone un avance hacia la unidad jurídica.

Es un avance hacia la libertad civil pues nunca se da mayor extensión a las leyes imperativas (por ejemplo, se restringe el derecho de saca foral) y, en cambio, se facilita la utilización de medios jurídicos que están vedados en el Código Civil y suponen una mayor libertad como ocurre con el artículo 13 de la Ley que permite a los vecinos de villa otorgar testamento mancomunado o por comisario.

Sin embargo, el problema fundamental al que el legislador debió enfrentarse fue, como en 1959, el de la troncalidad y los frecuentes conflictos de leyes, agravados por las reformas de 1990 en materia de vecindad civil.

\section{Las dos vizcainías}

Dice el artículo 12 de la Ley de Derecho Civil Foral del País Vasco de 1 de julio de 1992 que «a los efectos de este Fuero Civil, son vizcaínos quienes tengan vecindad civil en el Territorio Histórico de Vizcaya». Añade el mismo artículo que «aforado o infanzón es quien tenga su vecindad civil en territorio aforado».

Esto es, todos los vecinos de Vizcaya son vizcaínos siempre que mantengan su vecindad civil, que es un concepto regulado por el Código Civil, pero no todos los vizcaínos son aforados sino únicamente los que tienen su vecindad en territorio aforado, esto es, en la Tierra Llana o Infanzonado o en la parte aforada de las villas. Esta parte aforada puede comprobarse en los planos elaborados por los Ayuntamientos en cumplimiento de la disposición adicional 1. ${ }^{\mathrm{a}}$ de la ley y que han sido aprobados por las Juntas Generales de Vizcaya.

Hay pues vizcaínos aforados y no aforados, y ello plantea frecuentes conflictos que, conforme al artículo 16 deberán resolverse por medio de las normas del Código Civil, pero teniendo en cuenta que, por una serie de circunstancias históricas en las que debe destacarse la Ley XV del Título XX del Fuero, la situación del vizcaíno no aforado no se identifica con 
la de cualquier persona sujeta al Código Civil porque el vecino de Vizcaya mantiene conexiones con la tierra aforada que determinan que civilmente goce de un status especial

\section{Régimen civil de los vizcaínos no aforados}

Admitida la existencia de dos tipos de vecindad vizcaína, la de villa y la de anteiglesia, no hay ya dificultad en establecer quiénes son vizcaínos aforados. Había alguna confusión en el Código Civil, cuando se refería a «los vizcaínos aunque residan en las villas» porque parecía exigir la residencia, no la vecindad, como condición de la vizcainía no aforada. Y la misma confusión se podía dar en la Compilación cuando hablaba de «los vizcaínos, aunque residan en territorio distinto del foral de Vizcaya».

La cuestión queda aclarada en la nueva ley en su artículo 13, del cual se desprende:

1. Que son vizcaínos «quienes tengan vecindad civil en el Territorio Histórico de Bizkaia».

2. ${ }^{\circ}$ Aforado o infanzón «es quien tenga su vecindad civil en territorio aforado» (art. 12, párrafo $2 .^{\circ}$ ).

3. ${ }^{\circ}$ Vecinos de villa son simplemente los vizcaínos no aforados, a quienes se refiere el artículo 13 y corrobora el artículo 23 .

\section{Especialidades de la vizcainía aforada}

El vizcaíno no aforado es, en principio, una persona sometida en todas sus relaciones personales y familiares al Código Civil. Sin embargo, por una tradición que procede del principio de territorialidad troncal, el no aforado se encuentra sujeto al Fuero en cuanto a los bienes que posea en la Tierra Llana.

A esta particularidad, limitada a los bienes troncales, la nueva ley civil foral añade una nueva, al permitir a los no aforados otorgar testamento mancomunado o por comisario (art. 13). En consecuencia, los no aforados:

a) Están sujetos a las normas forales sobre troncalidad.

b) Pueden otorgar testamento mancomunado o por comisario. Esta posibilidad se introdujo en la nueva ley por el justo deseo de aproximar las dos legislaciones vigentes en Vizcaya evitando algunas contradicciones demasiado frecuentes. Para ello se hicieron reformas importantes en materia de legítima viudal, sucesión intestada, etc., y especialmente se eliminó el derecho de saca foral (la institución más conflictiva en materia de troncalidad) de las 
zonas urbanas, una gran parte del territorio vizcaíno, al mismo tiempo que se hacía avanzar el Fuero respecto a los no aforados permitiéndoles otorgar testamento mancomunado y por comisario, lo que resultaba imprescindible para resolver los conflictos que plantea la diversidad civil entre marido y mujer (art. 13).

El Gobierno impugnó este artículo 13 ante el Tribunal Constitucional, por entender que la Comunidad Autónoma no puede hacer avanzar las instituciones forales sobre territorio no aforado. Sin embargo, esta competencia corresponde a la Comunidad Autónoma conforme al artículo 10.5 del Estatuto de Autonomía que le permite fijar el ámbito de su vigencia, lo que, como declaró el Consejo de Estado en su dictamen de 5 de agosto de 1993 «no es una novedad en el derecho civil vizcaíno» pues el artículo 10 de la Compilación se aplicaba a los no aforados. Además, esta norma «tampoco altera el régimen de vecindad civil del Código Civil y respeta las reglas de conflicto establecidas en el mismo».

\section{La troncalidad}

La troncalidad es, sin duda, la institución más singular del Derecho vizcaíno. Es cierto que aparece regulada en otras legislaciones (Aragón, Navarra) pero en ninguna con los acusados rasgos que presenta en Vizcaya, donde se convierte en el eje de casi todas las relaciones civiles, especialmente en materia sucesoria.

La gran extensión que el Fuero concedió a la troncalidad no se encuentra tampoco en leyes extranjeras, y esta circunstancia nos obliga a reflexionar no solamente sobre la posible mejora de la institución sino incluso respecto de su subsistencia misma. La correcta regulación de la troncalidad dentro de sus límites razonables es la tarea que en el próximo futuro se abre a los juristas vizcaínos. La nueva ley vasca de Derecho Civil Foral avanza en esta dirección tratando de acomodar la troncalidad a la sociedad moderna como cuando restringe en varios aspectos el derecho de saca o lo concede a los arrendatarios; pero probablemente hay que ahondar en el tema buscando soluciones más avanzadas.

La troncalidad, como ya sostuvo Chalbaud ${ }^{19}$ es una conexión entre la propiedad y la familia vizcaína y puede jugar su papel en el mantenimiento de la unidad y cohesión familiar, pero no es posible que tenga hoy la misma formulación que a la salida de la Edad Media.

19 Chalbaud y ErrazQuin, Luis. La troncalidad en el Fuero de Vizcaya, Bilbao, 1898, pp. 17 y s. 


\section{La territorialidad}

Dice el artículo 17 de la Ley de Derecho Civil Foral vasca:

«1. La propiedad de los bienes raíces es troncal. A través de la troncalidad se protege el carácter familiar del patrimonio.»

La declaración que hace este artículo hay que relacionarla con la reforma del título preliminar del Código Civil por la Ley de 17 de marzo de 1973. En su redacción original el Código decía que «los bienes inmuebles (están sujetos) a las leyes del país en que estén sitos», afirmación que tenía la amplia excepción del párrafo segundo en materia sucesoria.

En la actualidad, el mismo artículo 10 declara, sin más concreción, que «la posesión, la propiedad, y los demás derechos sobre bienes inmuebles, así como su publicidad, se regirán por la ley del lugar en que se encuentren».

Cuando la ley vasca declara que la propiedad de los bienes raíces es troncal, está diciendo que el principio de troncalidad es territorial, se aplica siempre a los bienes sitos en Vizcaya, como reconoce el artículo 10 del Código Civil de acuerdo con la mejor doctrina internacional.

La propiedad es troncal y territorial en Vizcaya. Y este principio debe aplicarse con carácter general, tanto a la propiedad en sí misma, como a las normas relativas a su transmisión, formas de publicidad e inscripción, las donaciones o ventas (no en su aspecto contractual) e incluso los derechos reales limitados.

Más discutible resulta la territorialidad en materia de sucesiones, a la vista del artículo 9.1 del Código Civil.

\section{Extensión del artículo 17}

Limitándonos a las enajenaciones inter vivos, el artículo 17 evita reiterar el antiguo párrafo tercero del artículo 10 del C.C. o el texto del artículo 10 de la Compilación. La troncalidad es territorial y, por ello, «en virtud de la troncalidad, el titular de los bienes raíces solamente puede disponer de los mismos respetando los derechos de los parientes tronqueros» (art. 17.2) pudiendo ser impugnados los actos que la vulneren (art. 17.3).

La extensión que adquiere la troncalidad en estos preceptos puede parecer excesiva. Resulta algo violento que una persona alejada del Derecho vizcaíno (un catalán, un castellano o un extranjero) que adquiere una finca en Vizcaya quede sometida a las restricciones que impone la troncalidad, llamamientos forales, legítima troncal, etc. 
De aquí que se hayan establecido en el artículo 23 unas reglas que, sin decirlo expresamente, limitan el principio troncal. Dice este artículo que «los derechos y obligaciones derivados de la troncalidad corresponden como vizcaínos a todos los que tengan vecindad civil en Bizkaia». Es una nueva versión de aquel principio, ya contenido en el Fuero y en el Código Civil, de que los vecinos de villa han de guardar el Fuero en cuanto a los bienes que poseen en la Tierra Llana.

Todos los vecinos de Vizcaya están sujetos a esta norma, siempre que conserven la vecindad vizcaína aforada o no aforada, aunque cambien de residencia.

\section{Limitaciones}

A sensu contrario habría que entender que los no vecinos de Vizcaya no están sujetos a las leyes troncales, pero esto daría lugar a que los derechos de la familia troncal pudieran ser vulnerados por un cambio de vecindad del titular de los bienes. Para evitarlo, el párrafo segundo del artículo 23 añade que «por esencia de la troncalidad, la pérdida de la vecindad vizcaína, no supone restricción alguna en los derechos y deberes derivados de la misma».

Esta norma se declara esencia de la troncalidad, porque ciertamente el principio troncal debe obtener la protección de la familia independientemente de los cambios de vecindad de su titular. El protagonista en las instituciones troncales es la familia y su protección no exige extender las instituciones forales hasta el infinito, pero sí mantenerlas mientras exista un miembro de la familia troncal.

En consecuencia:

Primero. Los derechos de troncalidad corresponden a quienes tengan vecindad civil en Vizcaya e incluso a los vizcaínos que la hubieren perdido. Esto significa que el pariente tronquero, hijo, hermano, etc., del titular, mantiene su derecho de troncalidad aunque pierda la condición de vecino de Vizcaya. Nadie podrá escudarse de que el tronquero es andaluz o naturalizado alemán para negarle, por ejemplo, el derecho de saca o de recibir una donación, como ha ocurrido en algunas decisiones de los tribunales.

Segundo. Las obligaciones que nacen de la troncalidad se mantienen también, pese a la pérdida de la vecindad vizcaína. Por lo tanto, el titular no podrá transmitir los bienes fuera de la familia troncal, aunque haya dejado de ser vizcaíno. Estará sujeto a los llamamientos forales, deberá respetar la legítima troncal, etc. Es preciso tener en cuenta que para el titular de los bienes, la troncalidad, que no es otra cosa que una limitación de la facultad de disponer, no supone derechos sino obligaciones y cargas. 
Tercero. No obstante, la troncalidad tiene sus límites. Si no existen parientes tronqueros, vizcaínos al menos de origen, o arrendatarios con derecho a saca, nadie podrá reclamar derechos troncales, y, por lo tanto, no existirán las correlativas obligaciones.

De esta forma, el artículo 23 hace una importante limitación al principio de troncalidad que genéricamente podía desprenderse del artículo 17, una limitación que está en la línea de los precedentes del Código Civil y la Compilación.

Cuarto. Conforme al artículo 23 la aplicación de la troncalidad sobre los bienes sitos en Tierra Llana tiene, por lo expuesto, un límite personal. No tendrá lugar cuando el transmitente no sea vizcaíno ni lo haya sido nunca (a menos que tenga parientes tronqueros de vecindad vizcaína) y que desciendan del tronco. En el derecho de saca funcionará también la troncalidad si existe un arrendatario que cumpla los requisitos del artículo 126 de la Ley Foral vasca.

\section{Naturaleza de la norma del artículo 23}

El artículo 23 es una norma por la que el legislador vasco limita los efectos del artículo 17. Conforme a la regla de conflicto del artículo 10 del Código Civil, la troncalidad debe regirse por la ley de situación de los bienes inmuebles, por ser una institución esencial de la propiedad vizcaína. Esta norma debe aplicarse sin atender a la naturaleza o vecindad de las personas porque el Código no exige una segunda conexión; pero esto puede dar lugar a consecuencias que parecen excesivas y desbordan el ámbito de la troncalidad vizcaína.

El artículo 23 limita la territorialidad añadiendo unos presupuestos de carácter personal. Ciertamente se trata de una norma de colisión, pero que tiene sus precedentes en el artículo 10 de la Compilación o en el párrafo tercero del artículo 10 del Código Civil. Son preceptos que resultan esenciales al Derecho vizcaíno y se enraizan en la Ley XV del Título XX del Fuero, por lo que pocas dudas podía haber sobre la competencia de la comunidad autónoma para actualizarlas.

Es cierto que el artículo 149 de la Constitución reserva al Estado en exclusiva la competencia respecto de la solución de los conflictos de leyes, pero también es verdad que hubiera sido imposible legislar adecuadamente sobre troncalidad sin atender a poner al día los precedentes y resulta quimérico pensar en que lo hicieran las Cortes Generales. Ciertamente que, si la ley foral hubiera optado por una subversión total de los precedentes legislativos citados podría ser discutida su oportunidad, pero cuando simplemente se hace una acomodación o actualización de la misma norma no puede haber duda de que quien puede y debe hacerlo no es 
otro que el Parlamento vasco. Y una prueba bien evidente de ello es que el Gobierno no formuló recurso contra el artículo 23.

Las leyes anteriores (Compilación y Código Civil), para evitar las posibles violaciones de la troncalidad, determinaron que los vecinos de villa queden sujetos al Fuero respecto de los bienes que poseen en la Tierra Llana; y la nueva Ley Foral dice lo mismo de otra manera, aunque penetra más en el sentido y razón de ser de la norma, que no es otro que proteger la familia troncal frente a los posibles cambios de vecindad del titular de los bienes.

Si un alemán, pongamos por ejemplo, adquiere una finca en Tierra Llana, cuando trate de venderla debiera verse obligado a dar los llamamientos forales y atenerse a la posible saca de los tronqueros, en aplicación del artículo 17 de la Ley foral conjugado con el artículo 10 del Código civil. El artículo 10 elimina esta posible obligación, puesto que el titular no es ni ha sido nunca vizcaíno ni tiene parientes tronqueros. La única excepción, a mi juicio, sería la existencia de un arrendatario con derecho de saca.

\section{La triple conexión}

El Código Civil y la Compilación imponían dos puntos de conexión para la aplicación de la troncalidad: primero, la situación de los bienes en Tierra Llana, y en segundo lugar, que el titular de los bienes fuera vizcaíno, aforado o no, de villa o de anteiglesia.

La sentencia del T.S. de 6 de marzo de 1965 añadió una tercera exigencia mucho más restrictiva (tercera conexión) pues entendía que, además, el tronquero o familiar que pretendiese poseer un derecho de troncalidad fuera vizcaíno, y no de villa sino aforado, vecino de Tierra Llana. «Los derechos que concede y obligaciones que impone el Fuero de Vizcaya, decía, son peculiares de los vizcaínos aforados, sin que quienes no gocen de él, por estar sometidos al Derecho común puedan conseguir derechos fundándose en una institución foral privilegiada.»

Esta doctrina, enormemente limitativa de la troncalidad, pero aceptada en algunos Tribunales inferiores, dio lugar a resoluciones tan restrictivas como la de estimar que un hijo no tiene derechos de troncalidad por haber perdido la vecindad foral. La decisión es sorprendente, pues ninguna legislación de un país civilizado priva de derechos sucesorios a los extranjeros o a quienes han perdido la nacionalidad. Se puede limitar la territorialidad atendiendo al titular de los bienes, pero obligar, por ejemplo, a un padre, a separar de su patrimonio a los hijos que no gozan de su misma condición de vecindad o ciudadanía es realmente increíble. 
La nueva ley no prescinde de considerar las circunstancias personales que dieron lugar a la triple conexión, pero no cae en consecuencias absurdas pues lo que busca, en todo caso, es la permanencia de la familia troncal vizcaína.

En consecuencia, se exige:

1. Una conexión real. Solamente cabe la troncalidad cuando los bienes radiquen en la Tierra Llana de Vizcaya (art. 17) y este requisito no puede tener excepción alguna. No se trata, sin embargo, de una territorialidad absoluta sino que está moderada por la exigencia de una conexión personal.

2..$^{\circ}$ Una conexión personal. Hace falta un elemento personal, pero no se acumulan dos exigencias como lo hacía la sentencia que hemos citado. Por el contrario, la conexión personal, que es indispensable, puede manifestarse en dos formas:

a) Cuando el titular es vizcaíno, aforado o no, o fue vizcaíno y ha perdido la vecindad (art. 23). En este caso mantiene los derechos y las obligaciones derivados de la troncalidad, dice el artículo 23. Lo cierto es que la troncalidad, para el titular de los bienes no es ningún derecho sino una serie de obligaciones que se presentan en el momento en que pretenda enajenar los bienes. De aquí que la cuestión hay que centrarla en las obligaciones del titular (si ha de hacer una reserva hereditaria o los llamamientos forales, etc.) y es preciso tener en cuenta que tales obligaciones no pueden existir si no hay un correlativo derecho, es decir, si no hay parientes tronqueros (art. 17.2).

b) Cuando hay parientes tronqueros con vecindad vizcaína, aforada o no. Estos parientes tienen derecho a exigir que se respeten sus preferencias (art. 17.2) y a impugnar los actos que las vulneren (art. 17.3) aunque el titular no sea vizcaíno ni lo haya sido nunca (art. 23). Y no importa que el pariente tronquero haya perdido la vecindad vizcaína, porque hay que evitar la injusticia que se produciría en caso de discriminar a los parientes por esta causa, dando, por ejemplo la sucesión troncal a los vecinos vizcaínos y quitándosela a quienes no lo sean.

En cambio, la aplicación del artículo 23 impide aplicar la troncalidad en favor de los hijos de aquel alemán que citábamos en el ejemplo, que nunca fueron vizcaínos, y esto es seguramente lo más acomodado al buen sentido.

En definitiva, lo que hace vigente el principio de troncalidad es el hecho de que existan parientes tronqueros de vecindad vizcaína, actual u 
originaria. Y no debe perderse de vista que, en cuanto al derecho de saca foral, el arrendatario se equipara al tronquero (art. 126) sin que tenga nada que ver la vecindad o nacionalidad del titular de los bienes.

\section{Consecuencias. Estatuto civil del vecino de villa}

La troncalidad es, sin duda, una limitación de la facultad de disponer, pero esta limitación opera de distinta forma según la naturaleza de los actos:

\section{A) Actos de disposición a título oneroso}

Cuando se vende o transmite a título oneroso un bien raíz, la troncalidad exige que se den los llamamientos forales por si algún tronquero quiere adquirirlos, y en el caso de que se omitan concede al tronquero el derecho de saca, esto es, la facultad de adquirir el bien raíz por el precio que fijen hombres buenos. Estos efectos deben producirse aunque el titular o el tronquero no sean vecinos de anteiglesia.

Antes de la Compilación, la sentencia del T.S. de 4 julio 1955 aplicaba correctamente el Código Civil al declarar que conforme al párrafo tercero del Código Civil «la determinación de troncales depende de la situación de los bienes y no de la condición de sus dueños», concediendo el derecho de saca a un vecino de villa.

La Compilación, en su artículo 10 no se refería a las enajenaciones onerosas y esto introducía problemas de interpretación que incluso pudieron dar lugar a la doctrina de la sentencia de 6 de marzo de 1965, que hemos comentado, y que exigía la condición de aforado en el tronquero que ejercita el derecho de saca (lo que hemos llamado tercera conexión). Una doctrina similar se contiene en la sentencia de 30 de noviembre de 1977.

Pienso que la cuestión queda clarificada en la nueva ley de Derecho Civil vasca, porque:

1. ${ }^{\circ}$ Conforme al artículo 17 (en conjunción con el art. 10 del Código Civil), tratándose del derecho de propiedad, de la publicidad de los modos de transmisión y de los derechos que surgen del incumplimiento de los requisitos de la troncalidad, la ley del lugar en que los bienes están sitos debe aplicarse sin excepciones.

2..$^{\circ}$ Esta regla general no resultará aplicable cuando no exista ningún pariente tronquero (condición esencial según el art. 17) ni un arrendatario que cumpla los requisitos del artículo 126 de la ley foral. El estatuto real es no solamente aplicable a los vecinos de villa, sino también a los no vizcaínos cuando existan parientes tronqueros, esto es, familia vizcaína. 


\section{B) Actos de disposición a título gratuito}

La Compilación derogada extendía la troncalidad en los actos de disposición a título gratuito a todos los vizcaínos, incluso los vecinos de villa, lo que no dejaba de plantear algunos problemas de los que me ocupé en otro lugar ${ }^{20}$.

La nueva ley civil vasca recoge los dos principios, enfrentados al menos aparentemente, que rigen esta materia:

a) El principio de territorialidad lo impone el artículo 10 del Código Civil en relación con el artículo 17 de la ley vasca al que repetidamente nos estamos refiriendo. La propiedad de los bienes raíces en Vizcaya es troncal, y por tanto territorial. La troncalidad es una serie de limitaciones a la facultad de disponer, similar a otros derechos de preferencia, que deben aplicarse a todos en virtud de la territorialidad. Si un acto de disposición vulnera los derechos de los parientes tronqueros puede ser impugnado en la forma prevista por la ley (art. 17.2 y 17.3). La troncalidad obliga a aforados y no aforados, siempre que existan tronqueros.

b) Por otra parte y conforme al artículo 9.1 del Código Civil, la sucesión por causa de muerte se rige por la ley personal, determinada por la nacionalidad o la vecindad. El artículo 9.8 añade que «la sucesión por causa de muerte se regirá por la ley nacional del causante en el momento de su fallecimiento, cualesquiera que sean la naturaleza de los bienes y el país en que se encuentren».

Por lo tanto, la sucesión se regirá por la ley del causante, pero esta regla no es absolutamente rígida como lo pone de relieve el propio artículo 9.8 cuando mantiene la validez de los testamentos otorgados conforme a la ley anterior y la de los pactos sucesorios.

Por lo tanto el problema consiste en conjugar el principio de territorialidad con el de personalidad de la sucesión, habida cuenta de que ambos son conciliables, como lo prueba el propio texto que hemos citado. Y esta conciliación de los dos principios antagónicos es lo que pretende la nueva ley foral en su artículo 25, según el cual, «quienes no sean vizcaínos aforados gozarán de libertad para disponer, a título gratuito de los bienes troncales en favor de cualquiera de los parientes tronqueros, pero el beneficiario de los mismos no podrá tener participación en los bienes no troncales mientras con ellos no esté cubierta la legítima estricta de los demás legitimarios».

20 En Vizcaya y su Fuero Civil, pp. 193 a 196, Comentarios al Código Civil y legislaciones forales de Edersa, tomo XXVI p. 121, etc. 
Esta norma se aplica siempre que el titular de los bienes no sea vizcaíno aforado y existan parientes tronqueros (art. 17) vizcaínos, o que siendo originariamente vizcaínos hubieran perdido esta vecindad (art. 23) pues de lo que fundamentalmente se trata es de salvar los derechos de los tronqueros.

La aplicación del artículo 25 exige el respeto de las legítimas que el precepto legal trata de conciliar con la reserva troncal. Cuando no haya legitimarios no se produce ningún conflicto, por lo que el derecho de los tronqueros ha de respetarse sin ninguna duda.

En nuestro Código Civil no hay otra legítima que la de los ascendientes y los descendientes (art. 806) dado que la cuota usufructuaria del viudo puede perfectamente conciliarse con la reserva troncal.

De ordinario no habrá conflicto entre los hijos y un pariente tronquero porque los hijos son tronqueros con preferencia a todos los demás (art. 20 de la ley vasca) salvo la posible excepción de los hijos de un matrimonio de un viudo cuando los bienes procedan del primer cónyuge.

El artículo 20 está pensado para los conflictos entre los propios hijos, y obliga, en todo caso, a respetar la llamada legítima estricta, que solamente existe en esta línea de sucesión. El titular de los bienes puede dejar los troncales a uno de los hijos, pero deberá respetar la legítima estricta de los demás. Si el bien troncal es de cuantía tan alta que no cubre los dos tercios de la herencia, no podrá el beneficiario elegido tener parte en los demás bienes. A mi juicio, la referencia a la legítima estricta no significa que la legítima amplia pueda ser vulnerada cuando el bien troncal supere los dos tercios de la herencia. El artículo 25 parece suponer que la reserva troncal se incluye en el tercio de mejora si excede de la legítima estricta.

Si los herederos forzosos o legitimarios son los ascendientes, el conflicto se puede producir entre los mismos ascendientes pues unos pueden ser tronqueros y otros no; o entre los ascendientes no tronqueros y un pariente colateral. La regla del artículo 25 no parece pensada para estos conflictos, pero su sentido es claro y obliga a respetar la troncalidad pero también la legítima. Los bienes troncales deben ir a los parientes tronqueros y la legítima de los ascendientes se ha de satisfacer con los bienes restantes.

¿Qué hacer cuando los bienes restantes no alcancen a cubrir la legítima? El criterio del artículo 25 es el de hacer prevalecer en todo caso la troncalidad, pero me parece difícil que este criterio sea aceptado por los tribunales, pues eliminaría totalmente la libertad de testar.

Aunque el artículo 25 piensa solamente en los conflictos de la ley foral con el Código Civil (la legítima estricta es una institución peculiar del Código) no hay que excluir que puedan producirse conflictos con 
otras legislaciones, españolas o extranjeras. La acomodación de las mismas a la troncalidad tendrá que hacerse en cada caso concreto mediante una interpretación del artículo 25 y los textos de las leyes con las que pueda enfrentarse.

El artículo 25 deberá aplicarse también, y con más razón, cuando la enajenación tenga lugar por donación u otro título gratuito inter vivos, pues aunque el artículo 10.5 del Código Civil permite a las partes elegir libremente la ley aplicable, lo que nunca podrán pactar válidamente es la vulneración de normas imperativas como son las de la troncalidad (art. 6.3 del Código Civil).

\section{C) La sucesión ab intestato}

Antes de la publicación de la Compilación, hubo una fuerte polémica entre los juristas a medida que el T.S. fue extendiendo a los distintos territorios forales la doctrina iniciada por las sentencias de 10 y 13 junio de 1914 (para Vizcaya en 31 enero 1950) que sostenía que la Ley de Mostrencos de 1835 derogó las normas forales en materia de abintestato ${ }^{21}$.

Superada esta cuestión por las Compilaciones forales, que mantuvieron vivas las normas propias de cada territorio en esta materia, el problema en Vizcaya es el de precisar lo que ocurre cuando un vecino de villa (u otra persona no aforada) fallece dejando bienes troncales en la Tierra Llana.

Bajo el régimen anterior a la ley foral vasca se discutía si las normas forales del ab intestato debían aplicarse a los vecinos de villa que tuvieran bienes en la Tierra Llana. La opinión negativa se defendió con diversos argumentos 22 y fue seguida también por la Audiencia Territorial de Burgos en sentencia de 15 de diciembre 1953 según la cual en la sucesión legítima ha de aplicarse siempre el Código Civil (aunque esta sentencia es anterior a la Compilación).

Nos inclinamos decididamente por la aplicación del Fuero en estos $\operatorname{casos}^{23}$ y con más razón después de publicada la Ley de Derecho Civil vasco de 1 de julio $1992^{24}$ porque su artículo 23 no subordina la aplicación de la troncalidad a la naturaleza o modos de la transmisión sino al

21 Me ocupé extensamente de este tema en Vizcaya y su Fuero Civil, obra ya citada, pp. 196 a 210.

22 Puede verse especialmente el comentario de Angel SÁnCHEZ DE LA TORRE en «El párrafo tercero del artículo 10 del Código Civil» en Rev g. de Leg. y Jur. 1958, p. 45.

${ }^{23}$ En Vizcaya y su Fuero Civil, pp. 211 y siguientes.

${ }^{24}$ En el mismo sentido ANDrÉs M. URRUTIA BADIOLA en la obra colectiva El Derecho Foral Vasco tras la reforma de 1992, Bilbao, 1994, p. 45. 
hecho de que existan «derechos» de los tronqueros que no pueden ser vulnerados. Sería una incongruencia que pudiera lograrse muriendo intestado lo que no está permitido haciendo testamento.

Como decia Vallet de Goytisolo ${ }^{25}$, «es sabido que las legítimas se imponen a la voluntad formalmente expresada del causante, por tanto, con mayor razón, han de ser aplicadas si falta la expresión de voluntad. ¿Cómo sería posible entender que aquello que la ley prohíbe al testador por una razón considerada de derecho necesario, deba tener lugar cuando falta la voluntad expresa del causante? Admitirlo sería aceptar un criterio de contradicción legalmente absurdo. Resultaría que lo vedado a la voluntad expresa, para poder conseguirlo bastaría con dejar discurrir el intestado».

Si el titular no puede vender ni donar la finca fuera del tronco, ni puede testar a favor de quien no es tronquero ¿cómo se le puede permitir hacerlo con el simple expediente de no testar sobre el bien troncal?

Pero además, si se aplicara el Derecho común a la sucesión intestada se daría la paradoja de que el pariente que consiguiera la nulidad de una disposición a favor de quien no es tronquero no lograría que la finca vuelva al tronco sino al heredero llamado ab intestato por el Código Civil.

\section{Modos de testar autorizados a los vecinos de villa}

La distancia entre la ley foral y el Código Civil es muy grande en varias materias, pero en cuanto a los caracteres del testamento es seguramente excesiva.

El artículo 669 del C.C. declara que «no podrán testar dos o más personas mancomunadamente o en un mismo instrumento» con lo que afirma la que se denomina unilateralidad del testamento, en el sentido de que ha de ser otorgado por una sola persona. La prohibición es tan tajante que tampoco se reconoce la validez del testamento mancomunado que los españoles otorguen en el extranjero. En cambio, la ley civil vasca en su artículo 49 permite a los cónyuges otorgar testamento mancomunado.

Por otra parte el artículo 670 afirma que el testamento es un acto personalísimo, y que «no podrá dejarse su formación, en todo ni en parte, al arbitrio de un tercero, ni hacerse por medio de comisario o mandatario». Y, por contraste, los artículos 32 y siguientes de nuestra Ley foral permiten encomendar a uno o varios comisarios la designación de sucesor.

25 Juan B. Vallet de Goytisolo, «Glosas al párrafo tercero del artículo 10», en Anuario de Derecho Civil 1960, p. 579. 
Conforme al artículo 13 de la nueva ley civil foral esta posibilidad de testar en forma mancomunada o por comisario se concede también a los vecinos de las villas. Se hizo esta ampliación de las formas de testar al ámbito de las villas de Vizcaya por varias razones:

En primer lugar porque la nueva legislación permite que el marido y la mujer tengan vecindad distinta, conservando la de solteros, por lo que en Vizcaya, donde son tan frecuentes los matrimonios de aforado y vecino de villa, sería muy difícil que el aforado pudiera hacer uso de las formas forales que normalmente suponen una reciprocidad entre los cónyuges.

En segundo lugar, estos testamentos forales permiten disponer conjuntamente de los bienes comunes (gananciales o comunicados) lo que resulta muy difícil en las formas reguladas en el Código Civil, según el cual, al ser cada testamento independiente, no es posible asignar a un sucesor bienes conyugales determinados sino que se ha de disponer por partes del patrimonio global, un tercio o un quinto de los bienes, nunca de una cosa concreta y específica que pertenezca a ambos cónyuges.

Por último, el artículo 13 es una disposición que amplía la libertad del testador, le permite hacer lo que el Código le prohíbe por prejuicios dogmáticos no muy justificados. Resulta muy difícil entender que dos cónyuges que acuden al notario para otorgar testamento se encuentren que, si están sometidos al Código Civil, no pueden testar en un solo instrumento y deberán otorgar actos separados, sin poder disponer de común acuerdo de los bienes comunes. Su sorpresa será mayor si luego se les explica que cualquiera de ellos, una vez que hayan otorgado dos testamentos separados, podrá acudir cuando quiera a otro notario revocando el testamento otorgado y burlando la confianza del otro cónyuge. 